San Jose State University

SJSU ScholarWorks

Master's Theses

Master's Theses and Graduate Research

1997

\title{
Epidermal influence on leaflet and cell development in Pisum sativum var. argenteum
}

Mary Katherine Painter Wilson

San Jose State University

Follow this and additional works at: https://scholarworks.sjsu.edu/etd_theses

\section{Recommended Citation}

Wilson, Mary Katherine Painter, "Epidermal influence on leaflet and cell development in Pisum sativum var. argenteum" (1997). Master's Theses. 1535.

DOI: https://doi.org/10.31979/etd.sb6p-449c

https://scholarworks.sjsu.edu/etd_theses/1535

This Thesis is brought to you for free and open access by the Master's Theses and Graduate Research at SJSU ScholarWorks. It has been accepted for inclusion in Master's Theses by an authorized administrator of SJSU ScholarWorks. For more information, please contact scholarworks@sjsu.edu. 


\section{INFORMATION TO USERS}

This manuscript has been reproduced from the microfilm master. UMI films the text directly from the original or copy submitted. Thus, some thesis and dissertation copies are in typewriter face, while others may be from any type of computer printer.

The quality of this reproduction is dependent upon the quality of the copy submitted. Broken or indistinct print, colored or poor quality illustrations and photographs, print bleedthrough, substandard margins, and improper alignment can adversely affect reproduction.

In the unlikely event that the author did not send UMI a complete manuscript and there are missing pages, these will be noted. Also, if unauthorized copyright material had to be removed, a note will indicate the deletion.

Oversize materials (e.g., maps, drawings, charts) are reproduced by sectioning the original, beginning at the upper left-hand comer and continuing from left to right in equal sections with small overlaps. Each original is also photographed in one exposure and is included in reduced form at the back of the book.

Photographs included in the original manuscript have been reproduced xerographically in this copy. Higher quality 6" $x$ 9" black and white photographic prints are available for any photographs or illustrations appearing in this copy for an additional charge. Contact UMI directly to order.

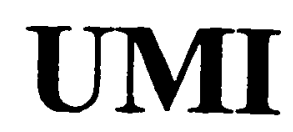

A Bell \& Howell Information Company 



\title{
EPIDERMAL INFLUENCE ON LEAFLET AND CELL DEVELOPMENT IN PISUM SATIVUM VAR. ARGENTEUM
}

\author{
A Thesis \\ Presented to \\ The Faculty of the Department of Biological Sciences \\ San Jose State University \\ In Partial Fulfillment \\ of the Requirements for the Degree \\ Master of Science
}

by

Mary Katherine Painter Wilson

August 1997 
OMI Number: 1386236

UMI Microform 1386236

Copyright 1997, by UMI Company. All rights reserved.

This microform edition is protected against unauthorized copying under Title 17, United States Code.

\section{UMI}

300 North Zeeb Road

Ann Arbor, MI 48103 
(c) 1997

Mary Katherine Painter Wilson

ALL RIGHTS RESERVED 
APPROVED FOR THE DEPARTMENT OF BIOLOGICAL SCIENCES
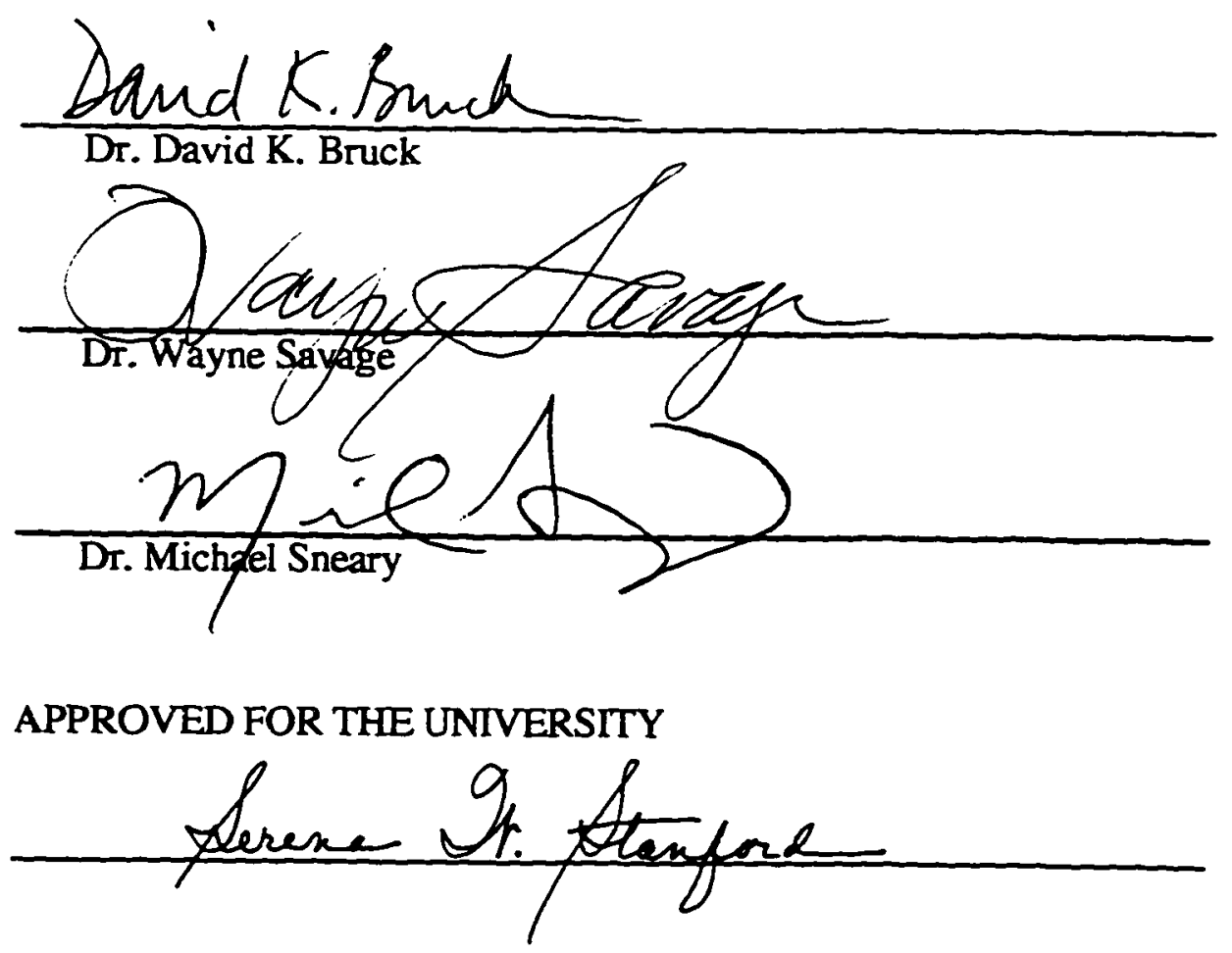


\section{ABSTRACT \\ EPIDERMAL INFLUENCE ON LEAFLET AND CELL DEVELOPMENT IN PISUM SATIVUM VAR. ARGENTEUM}

by Mary Katherine Painter Wilson

This investigation explored whether epidermal pressure regulates cell and organ growth and development in leaves of Pisum sutivum var. argenteum, a mutant cultivar of the garden pea characterized by minimal adhesion between the epidermis and subjacent mesophyll. Five young leaflets of leaves arising at three positions on the seedling axis were peeled in situ and grown to maturity in humidity chambers that eliminated wound responses by preventing desiccation of the peeled areas. The leaflets opposite to the peeled leaflets were left intact and also enclosed in humidity chambers. The mesophyll cell size, shape, state of differentiation, and layering pattern, and the overall morphology of mature, peeled leaflets were similar to those of mature, intact leaflets grown under the same conditions. The epidermis exerted no detectable regulatory effect on the growth and development of the leaves as a whole or on the tissue layers and cells within the leaves. 


\section{Acknowledgments}

Many people have contributed to my happy years at San Jose State University. I am grateful for the emotional and financial support of my husband, Dennis. He uncomplainingly put up with rushed meals and lack of companionship and cheerfully shared his knowledge of statistics and Microsoft Word when I needed help. My parents and children also were recipients of tales of woe and delight and cheered me on.

I am very grateful to my committee members, Dr. Bruck, Dr. Savage, and Dr. Sneary. for their encouragement and critical thesis readings. Dr. Bruck's suggestion some years ago that I attempt a Master's degree and his encouragement and patience as I completed my work were enormously helpful and very much appreciated. In addition to providing me with the knowledge, materials and lab space for my research, he helped me to see past the details and to find the larger perspective necessary to writing this thesis. Dr. Savage's expertise in botany and with the SEM were very helpful in developing my research and in assuring that this thesis was properly finished. Dr. Sneary cheerfully answered many questions regarding TEM and SEM technique. I have fond memories of passing the sodium sulfite bucket back and forth one semester when we both took weekly trips to Hayward to use the SEM. In addition, I want to thank Dr. Bros for contributing greatly to my understanding of statistics, for helping me determine which tests to use for my research, and for guiding me to accurate interpretations of the results.

Other people whose help I gratefully acknowledge are Carol Selter, who taught me to use the growth chambers and set aside room on the seventh floor for my project, and Vicki Jennings, who drew the fine scientific illustration in this thesis.

I enjoyed working with Dr. Bruck's other graduate students and often benefited from their different areas of expertise. Eileen Pacier was the first to share lab space with me. 
She suggested the dissecting dishes and gave me the insect pins that I used while peeling leaves. Cathy Greene was a kind and helpful lab partner in Immunologic Techniques. With them, Donna Brickner, Sunita Shah, Paul Sethi, Jeff Cochiolo, Ingrid Udransky and Albert Boot, I've taken classes, taught labs, or leamed to identify the trees on campus. During hours spent in Dr. Bruck's lab, we've listened to each other's thoughts, frustrations, hopes and music. I thank them all for their contributions and companionship.

This work could not have been completed without the use of the CSU Hayward SEM for which I thank Nancy Smith. Equally vital was Dr. Kerr's Jandel Video Analysis Software and associated computer and microscope. I appreciate the unstinting availability of this equipment.

My development as a scientist and a teacher was encouraged by many faculty members in addition to those already mentioned. My thanks, in particular, are due to Dr. Pitts, Dr. Kenk, and Dr. Myatt for spurring my curiosity about their subjects and for encouraging me in my teaching.

This work was supported by a San Jose State University Foundation Development Grant, a San Jose State University Foundation Student Stipend Award, and a California State University Faculty Development Mini-Grant.

The Pisum sativum var. argenteum plants used in this study are descended from a gift of seed from Dr. G. A. Marx of New York State Agricultural Experiment Station. 


\section{TABLE OF CONTENTS}

$\begin{array}{lr}\text { Abstract } & \text { iv } \\ \text { Acknowledgments } & \text { v } \\ \text { List of Tables } & \text { viii } \\ \text { List of Figures } & \text { ix } \\ \text { Introduction } & 1 \\ \text { Materials and Methods } & 3 \\ \text { Results } & 11 \\ \text { Discussion } & 21 \\ \text { Literature Cited } & 24 \\ \text { Appendix 1. Preliminary Operations } & 26 \\ \text { Appendix 2. Seed-Production Procedures } & 31 \\ \text { Appendix 3. Growth-Chamber-Cultivation Procedures } & 32 \\ \text { Appendix 4. Peeling Procedures } & 33 \\ \text { Appendix 5. Palisade cell height measurements using JAVA } & 34\end{array}$




\section{LIST OF TABLES}

Table 1. Results of RCB ANOVA tests on increases in Arg leaflet lengths from Day 1 to Day 11.

Table 2. Grand mean of Arg leaflet palisade mesophyll cell heights and minimum detectable differences, based on nested (heirarchical) ANOVA's

Table 3. The incidence of tissue caps seen in scanning electron micrographs of Arg leaflets from which epidermis was peeled at Day I or Days 8 or 11 . 


\section{LIST OF FIGURES}

Figure 1. Morphology of mature L1, L4, and L7 of $P$. sativum var. argenteum, showing the increase in leaflet size, petiole length, and complexity of tendrils that occurs with progression up the seedling axis.

Figure 2. Experimental protocol for peeled and intact (control) L1 leaflets.

Figure 3. Diagram of a humidity chamber enclosing a mature $\mathrm{L} 4$ of $P$. sativum var. argenteum.

Figure 4. Frequently encountered palisade cell shapes.

Plate 1. Figures 5 - 14. SEM and transverse sections of leaflets of $P$. sativum var. argenteum.

Plate 2. Figures 15 - 20. Transverse sections of mature Arg leaflets.

Plate 3. Figures 21 - 26. Scanning electron micrographs of mature Arg leaflets grown in humidity chambers from Day $1-11$.

Figure 27. Location of leaflet width and length measurements.

Figure 28. Average daily midrib lengths and side $b$ widths of five experimental and five control leaflets of $\mathrm{Ll}$ of Pisum sativum var. argenteum.

Figure 29. Average daily midrib lengths and side $b$ widths of five experimental and five control leaflets of L7 of Pisum sativum var. argenteum.

Figure 30. Immature LI on Day 1. 


\section{Introduction}

The effect of the epidermis on plant growth and development has been examined for over 100 years. Investigations of peeled and unpeeled axes have supported the hypothesis that the epidermis controls the elongation of stems and coleoptiles through a pressure effect coupled with a specific interaction between auxin and auxin receptors for cell expansion thought to be concentrated in the epidermal cell membranes (Thimann and Schneider, 1938; Masuda and Yamamoto, 1972; Cosgrove, 1986; Kutschera et al., 1987; Kutschera and Briggs, 1987, 1988; Napier and Venis, 1990: Jones, 1994). Leaves respond similarly to stems with regard to the control of elongation by the epidermis (Thimann and Schneider, 1938; Van Volkenburgh and Cleland, 1981).

Molecular approaches have revealed possible morphogenetic and histogenetic influences of the epidermis during plant development. Knolle, an Arabidopsis embryo mutant, and $t s I$, a carrot somatic embryo mutant, do not form normal protoderm and subsequently fail to continue embryogenesis (Goldberg et al., 1994), suggesting that the protoderm provides signals necessary for normal embryogenesis.

The epidermis appears to physically restrict the growth of internal tissues. When Sachs (1865) peeled the epidermis from stem segments, the excised epidermis subsequently contracted while the remaining segment elongated. Kutschera described the forces acting within the stem, hypocotyl, and coleoptile in which the internal tissues are under compression from the epidermis. At the same time, the internal tissues exert a strong outward counter-pressure due to cell expansion forces, resulting from their own turgor pressure, on the restrictive epidermis, which itself is elastic and under tension (Kutschera et al., 1987; Kutschera and Briggs, 1987, 1988; Kutschera, 1992). The outward bending of the free tips of longitudinally split stems and coleoptiles in the split pea test (Van Overbeek and Went, 1937) was cited in support of the concept of confining epidermal compression. Application of external pressure to the side of stems stimulated periclinal cell divisions in 
the underlying tissue (Lintilhac and Vesecky, 1981). The stiffness of the epidermis relative to inner tissues might influence the size and morphology of underlying cells and the number of tissue layers. The focus of this study was to determine whether the pressure exerted by the epidermis on underlying tissues during leaf ontogeny acts to restrict leaf expansion or to stimulate the periclinal cell divisions in developing mesophyll (of the plate meristem) and thus to control leaf morphogenesis and histogenesis as a whole.

The influence of the epidermis was investigated by removing epidermal strips from young, developing leaves in situ (still attached). The leaves were allowed to develop fully and the resulting morphology and anatomy compared to those of intact leaves of the same age. To ascribe to the epidermis a role in cell division and expansion of subepidermal tissues requires that removal of epidermis not by itself result in a wound response involving underlying cell divisions (as in wound periderm formation) or cell expansion (as in disorganized callus formation). First, peeled leaves were grown in a protective environment that minimized desiccation, which would increase the wound healing response. Second, Pisum sativum var. argenteum (Arg) was selected for the experimental work. While this garden pea mutant exhibits normal growth and physiology (Marx, 1978; Jewer et al., 1982; Aked and Hall, 1992), the epidermis is only loosely attached to the underlying mesophyll, making it especially easy to peel (Hoch et al., 1980). This study tested whether removal of the readily peelable epidermis of the mutant would lead to wound reactions that would be confused with responses resulting from the absence of an epidermal influence on lamina development. Hoch et al. (1980) found little damage to the mesophyll from leaf peeling. The compound leaf morphology of Arg was convenient, as opposite leaflets could be used as experimental and control specimens grown under identical conditions. 


\section{Materials and Methods}

\section{Growing Conditions}

Arg mutants of the garden pea (Pisum sativum var. argenteum) were grown individually in Supersoil Steam Sterilized Potting Mix® enriched with Nutricote Total 1313-13 Controlled Release Fertilizer $\circledast$. The seeds were germinated and the plants grown in controlled environment chambers with day/night temperatures of $20^{\circ} \mathrm{C}$ and $15^{\circ} \mathrm{C}$, respectively, and a $16 \mathrm{~h}$ photoperiod (Hoch et al., 1980). The plants were illuminated with a combination of fluorescent and incandescent lights producing a 1:1 ratio of red: far red light. When leaves developed actively twining tendrils, the plants were staked.

\section{Peeling Procedures}

Because successively arising Arg leaflets become increasingly more difficult to peel, their reaction to peeling might differ. Consequently, the basal pair of leaflets of the first (L1). fourth (L4) and seventh (L7) leaves initiated on seedlings (Fig. 1) were subjected to the experimental procedures.

The first day (Day 1) of the experimental period corresponded to the youngest possible stage at which the leaflet could be reached for peeling, permitting the maximum period of time for growth and development after peeling and before maturation. At this stage, about 2 days after the stipules enclosing each new leaf arose, the leaflets were $c a .8 \mathrm{~mm}(\mathrm{Ll}), 10$ $\mathrm{mm}(\mathrm{L} 4)$, or $13 \mathrm{~mm}(\mathrm{~L} 7)$ in length. The new leaf extended beyond its stipules by threequarters of its length, and the two basal leaflets were folded upward along their midribs and closely appressed.

On Day 1 of the experimental period, the experimental and control leaflets of L1, L4, and $L 7$ were measured (midrib length). The experimental leaflets were unfolded in situ (while still attached to the axis) and a strip of epidermis peeled from midrib to margin from the adaxial surface with jeweler's forceps (Fig. 2). Care was taken to avoid injuring the 
leaves beyond the peel. If minor bruises occurred in isolated areas well removed from the peeled region, leaflets were retained. Otherwise, injured leaflets were excluded from the experimental group. The experimental leaflets were refolded after peeling and returned to their original orientations. One leaf only $(\mathrm{L} 1, \mathrm{~L} 4$, or $\mathrm{L} 7)$ per plant was peeled. Sample size varied from four to seven plants but was always equal for experimental and control leaflets for the same procedure for the same leaf type (L1, L4, or L7).

\section{Humidity Chamber Construction}

To prevent desiccation and maintain high humidity in the newly exposed mesophyll after peeling. peeled and unpeeled (control) leaflets were enclosed in humidity chambers fashioned from plastic Petri dishes (Fig. 3). A notch to accommodate the petiole and 2 holes to accommodate brass screw-eyes were melted into the side of each dish bottom. Lanolin was applied to the inside of the top of the dish lid to seal the chamber. The screweyes were slid over dowels anchored in the soil, allowing for positioning of the chambers in height and attitude. Distilled water ( $1 \mathrm{ml})$ was sprayed through the petiolar notch in each humidity chamber once it was closed around a leaf. After the leaves were treated and enclosed, the plants were returned to the growth chamber where they were watered as needed. The humidity was maintained within the humidity chambers by transpiration as the leaflets expanded. The position of the humidity chambers was adjusted daily to minimize contact between the expanding leaflets and the walls of the chamber. Any leaves that consistently pressed against the chamber walls were excluded from the study.

\section{Peeling Damage Assessment}

A set of leaflets was prepared for immediate fixation on Day 1 of the experimental period. L1, L4, and L7 leaflets (5 plants each) were measured (midrib length), excised, and bathed in $2.5 \%$ gluteraldehyde in $0.05 \mathrm{M}$ sodium cacodylate buffer, $\mathrm{pH}$ 6.9. The 
leaflets were unfolded and a strip of epidermis peeled as described. A rectangular region of tissue that included the peeled area and the unpeeled border was excised (Fig. 2) and processed for microscopy.

\section{Deliberate Wounding}

Because the wound response of annual herbs such as the garden pea can be subtle, another set of five leaves each of LI, L4, and L7 was prepared on Day 1 to define the appearance of the wound response typical of leaves of this variety. Experimental leaflets were peeled as described above. In this case, however, they were refolded and returned to their original positions without enclosure in humidity chambers. The plants were returned to unhumidified growth chambers and left to mature. After 10 days, specimens were excised (Fig. 2) and prepared for SEM examination.

\section{Microscope Specimen Preparation}

After 10 days (Day 11), the midrib lengths of the experimental and control leaflets were again measured. Random Complete Block Analysis of Variance (RCB ANOVA) tests were used to compare the increase in the leaflet lengths over the experimental period ( $\mathrm{Zar}$, 1984). Portions of the peeled and intact leaflets were excised (Fig. 2), fixed in $2.5 \%$ glutaraldehyde in $0.05 \mathrm{M}$ sodium cacodylate buffer, $\mathrm{pH} 6.9$, for $2 \mathrm{~h}$, postfixed in $2 \%$ osmium tetroxide in the same buffer for $2 \mathrm{~h}$, stained en bloc with $2 \%$ aqueous uranyl acetate for $20 \mathrm{~min}$., and dehydrated in an acetone series. The specimens were cut into two portions for SEM and LM preparation (Fig. 2). The SEM specimens were critical point dried, mounted on stubs, sputter coated with gold-palladium, and viewed in a Philips XI40 SEM. LM specimens were further dehydrated with propylene oxide and infiltrated and embedded in Spurr's resin (Spurr, 1969). Sections 300-1000 nm in thickness were 
cut, mounted on microscope slides, and stained with $1 \%$ aqueous crystal violet or with methylene blue, azure A and basic fuchsin (Humphrey and Pittman. 1974).

\section{Palisade Cell Height Measurements}

The heights of palisade cells of intact and peeled $L 1, L 4$, and $L 7$ leaflets were measured in transverse sections by means of Jandel Video Analysis (JAVA) software (Jandel Scientific, Corte Madera. California) mounted on a Compudyne 3DX/33 PC with an Intel 32-bit processor. A TM-7CN miniature high resolution CCD camera (Pulnix Video Products, Sunnyvale, Califomia) carried the image to a video monitor. The JAVA software was used to measure the length of lines drawn between the centers of the outer and the inner tangential walls of palisade cell images on the video monitor (Fig. 4). The measurements were entered in a JAVA spreadsheet, transferred to Excel, and then imported into Systat for statistical analysis.

The following conventions were observed. Palisade cells considered proper in shape for measurement were longer in height than in width and were close to full height for cells in that section (Fig. 4). Cells were included as long as their long axes fell within $30^{\circ}$ of perpendicular to the surface of the leaflet. Three sections from each leaflet specimen were measured. The three sections were taken about $50 \mu \mathrm{m}$ apart to ensure that a cell was not measured more than once in different sections. Starting at the right edge of the peeled area. measurements were taken on the first properly shaped cell, as defined above, and continued for each properly shaped cell after that until 15 measurements were taken, omitting any cells distorted by knife marks or other defects.

The palisade mesophyll cell-height means were compared by nested (Hierarchical) ANOVA's (Zar, 1984). The necessary sample size was calculated by plotting the standard errors of a series of successively larger samples drawn randomly from preliminary data (Bros and Cowell, 1987). 


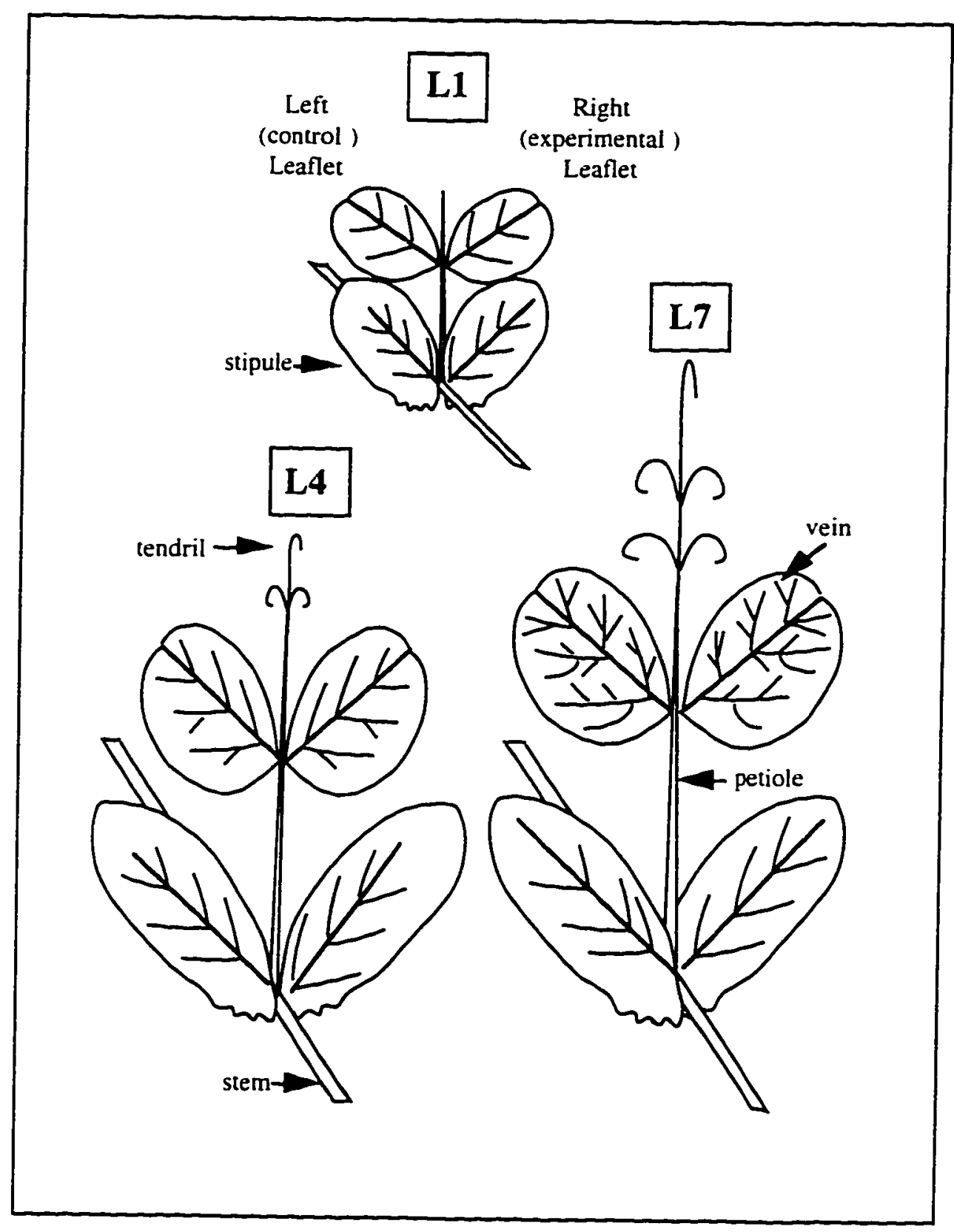

Fig. 1. Morphology of mature $\mathrm{Ll}, \mathrm{L} 4$, and $\mathrm{L} 7$ of $P$. sativum var. argenteum, showing the increase in leaflet size, petiole length, and complexity of tendrils that occurs with progression up the seedling axis. 


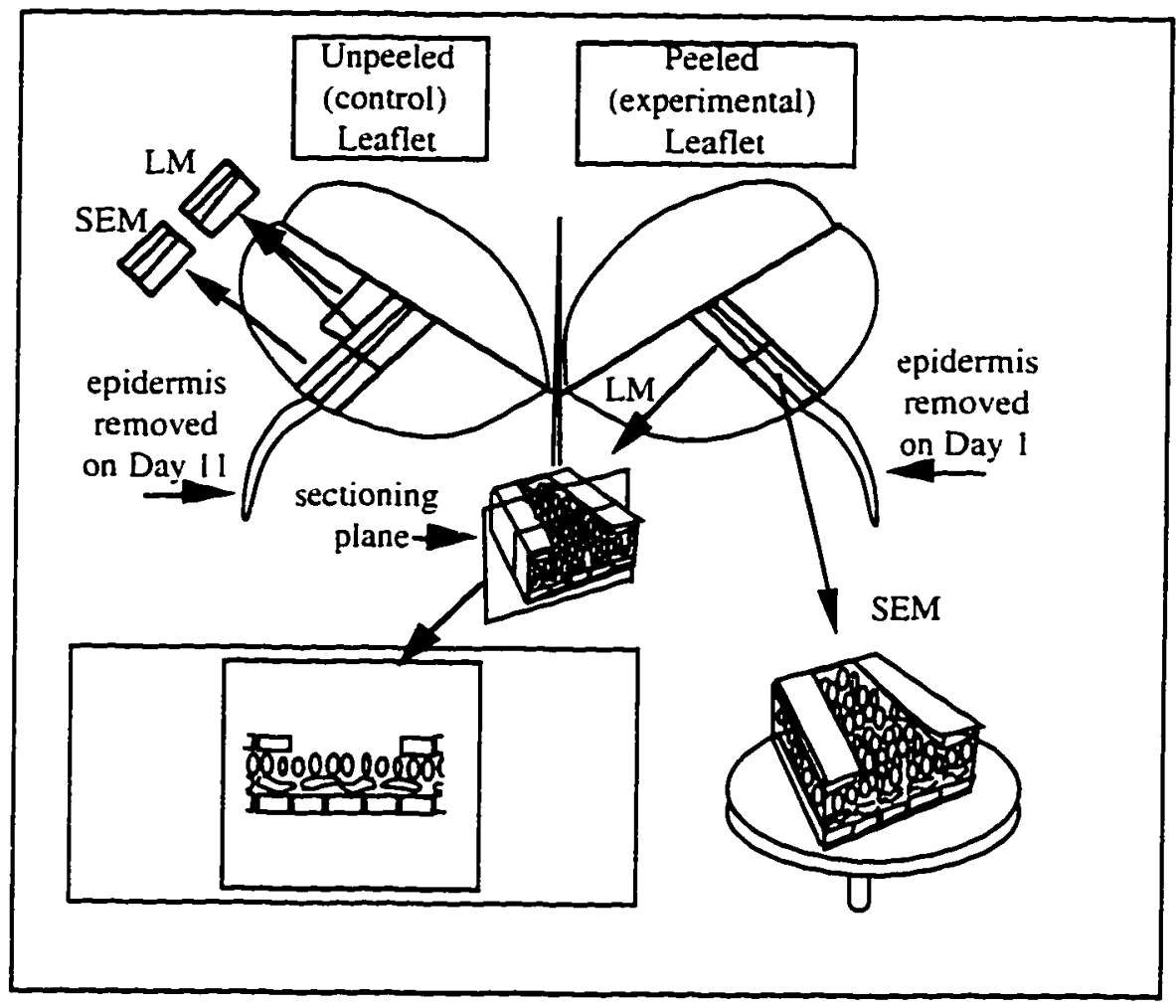

Fig. 2. Experimental protocol for peeled and intact (control) L I leaflets. On Day 1, the experimental leaflet was peeled. By Day 11, the leaflets had unfolded, the control leaflet was peeled, and specimens were excised for fixation. The processing of the excised specimens is indicated by arrows. 


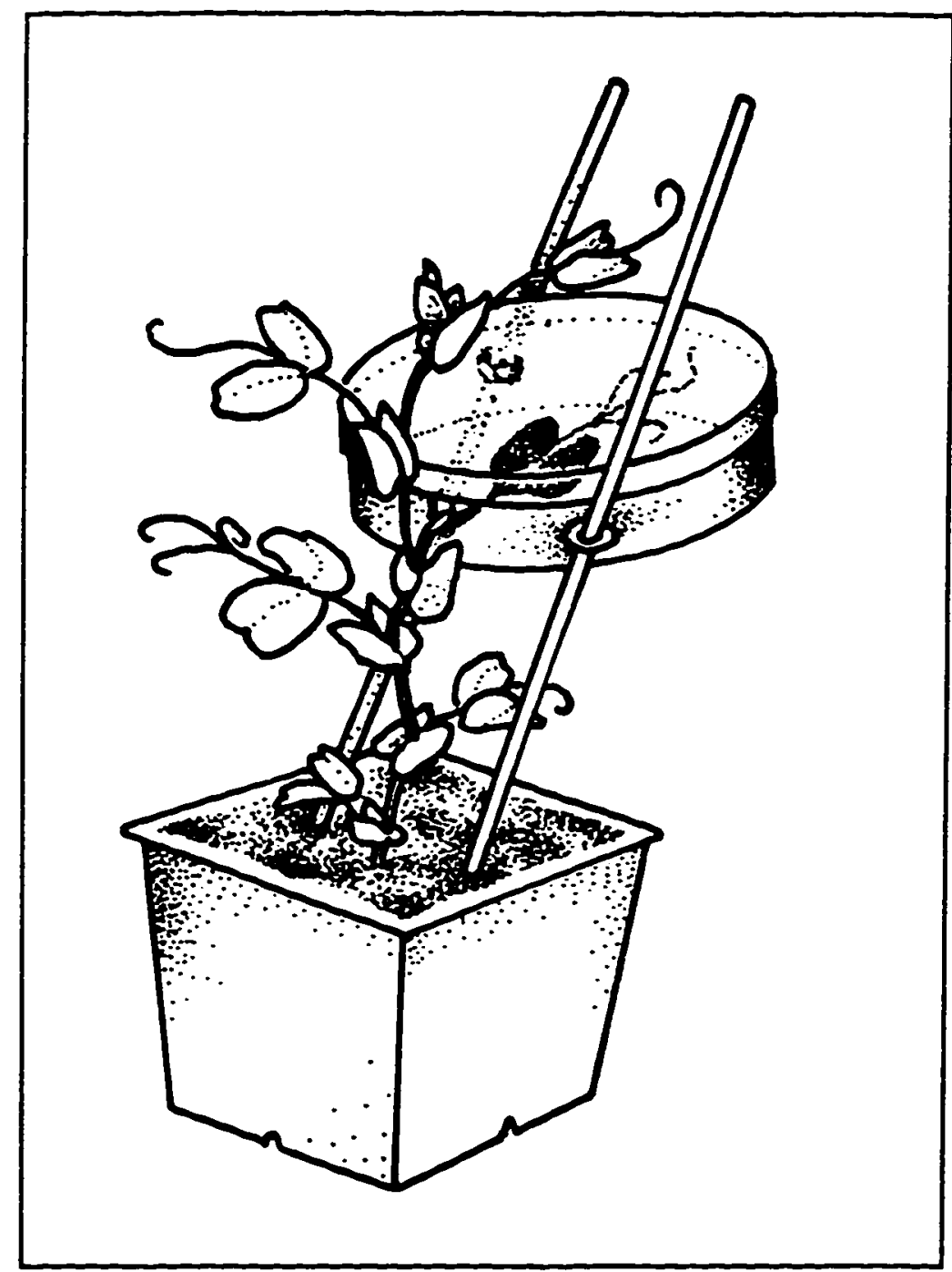

Fig. 3. Diagram of a humidity chamber enclosing a mature L4 of $P$. sativum var. argenteum. The humidity chamber, fashioned from a deep Petri dish to which screw eyes were attached, was mounted on dowels so that the attitude and height could be adjusted throughout the experimental period to accommodate changes in the leaf orientation. 


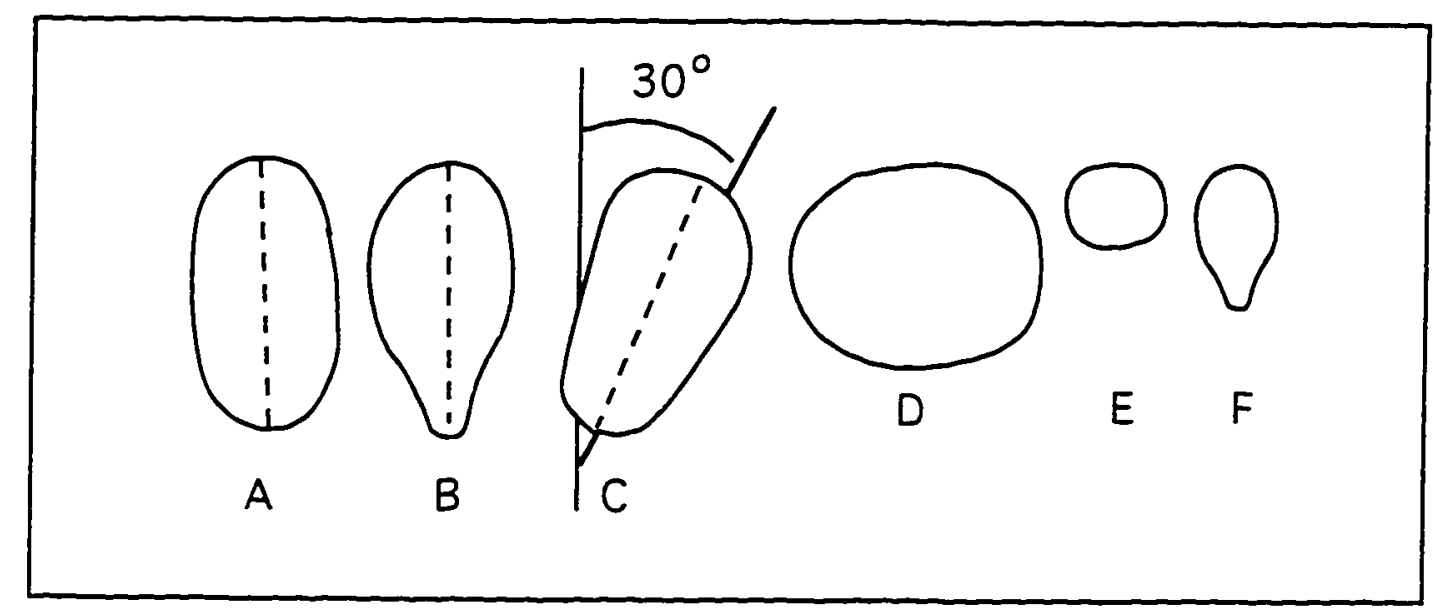

Fig. 4. Frequently encountered palisade cell shapes. Cell sections $A, B$, and C represent proper shapes, sizes, and orientations $\left(<30^{\circ}\right.$ from perpendicular from leaflet surface) for measuring. Cell sections $D, E$, and $F$ were unsuitable. Cell height measurement positions are represented by dashed lines. 


\section{Results}

\section{Deliberate Wounding}

Conspicuous and easily recognized wound responses resulted from peeling in conjunction with absence of leaf enclosure in humidity chambers. Wound responses resulted in the formation of flat, papery, tan-colored scar tissue and/or beaded, pale-green tissue composed of greatly enlarged cells, the surface of which were raised above nearby unpeeled areas (Fig. 5). The smooth papery tissue was observed to be the result of cell collapse (Fig. 6). Because leaflet expansion was restrained in the peeled region, distortions and folds developed as the rest of the lamina continued to expand. The midrib of the leaflet bent toward the wound.

\section{State of Maturity and Peeling Damage Assessment}

Leaflets were peeled on Day 1. soon after emergence from the seedling apical bud, and enclosed in humidity chambers, the results of which are described in the next section. At this early stage of development, the mesophyll cells were clearly immature. They were more densely cytoplasmic, smaller, more isodiametric, and more tightly packed than in mature leaflets (Figs. 7-9). The number of cell layers was difficult to count with precision, especially as cell shape became more irregular and intercellular spaces enlarged during development. The number, in fact, varied within a leaflet. Nonetheless, the number of both cells and cell layers was fewer at the time of peeling than at maturity in many of the leaflets. Regional differentiation into palisade and spongy mesophyll had just hegun.

The peeling itself produced no discernible changes under LM in the mesophyll of these peeled leaflets in comparison to unpeeled leaflets at the same developmental stage, including any tearing, puncturing, or other mechanical damage resulting from the peeling procedure (Figs. 12-14). Under examination by SEM, the palisade cells were tightly packed and squarish (L1 and L7), rounded (L1), or hexagonal (L4) in shape with no 
evidence of collapse, rupture, or other anomalies (Figs. 10, 11). Many of the cells were tightly appressed in pairs or trios, indicating recent or ongoing anticlinal cell divisions. Small caps of tissue fragments were visible on the outer tangential wall of some palisade cells (Fig. 11).

\section{Peeled Leaflet Anatomy}

Leaflets peeled on Day 1 and enclosed in humidity chambers were allowed to grow to maturity in the absence of putative epidermal pressure for 10 days (until Day 11). The gross morphology of peeled leaflets was similar to that of intact leaflets. Unlike leaflets that were deliberately wounded, the midribs of peeled and intact leaflets remained straight.

The transectional mesophyll anatomy under LM of these peeled leaflets (Figs. 15-17) was also similar to that of mature. opposite, unpeeled, control leaflets (Figs. 18-20). The cell morphology and number, the cell layering pattern, the state of differentiation, and the extent of the intercellular space system, as well as the vascular structure, were indistinguishable. Similarly, under the SEM, no differences in size and shape of palisade cells of peeled and control (peeled on Day 11 to reveal the underlying mesophyll for SEM viewing) leaflets were visible (Figs. 21-26). In both the experimental and control specimens, LI, L4, and $\mathrm{L} 7$ palisade cells were large, rounded on the outer tangential surface, although less so in L4, and packed together, allowing limited intercellular space volume (Figs. 21-26). Intercellular cell wall connections, forming short bridges between adjacent radial walls of palisade cells, were present in all leaf types but were more prevalent in L4 and L7 than in L1 (Figs. 21-26). Chloroplasts were more conspicuous in L4 and L7 palisade cells than in L1 palisade.

In peeled specimens, some abnormally elongated cells were found in four of seven $\mathrm{L} 1$ specimens and in two of five $\mathrm{L} 7$ specimens. These cells were found in low numbers and were limited in distribution, occurring singly or in short rows confined to the flanks of 
peeled areas (Fig. 22). For the cell height measurements below, the cells at the junction of the peeled region and the epidermis were excluded. None of the five peeled L4 specimens produced cells of this kind. As in all other peeled specimens, small tissue caps occurred occasionally on the outer tangential wall of some palisade cells. They were found at higher frequency in mature leaflets peeled on Day 11 than in immature leaflets peeled on Day 1 (Figs. 21, 25). This result is consistent with the fact that older leaves are harder to peel cleanly because they have more wall connections between the epidermis and mesophyll layers.

\section{Leaflet Length}

Increases in leaflet (midrib) lengths from Day 1 to Day 11 for L1, L4, and L7 peeled and control leaflets were compared by RCB ANOVA's (Table 1). No statistically significant differences were found between mean length increases of peeled and control leaflets.

Table 1. Results of RCB ANOVA tests on increases in Arg leaflet lengths from Day 1 to Day 11.

\begin{tabular}{cccc} 
Grand Mean & Sample Size & $\begin{array}{c}\text { Minimum Detectable } \\
\text { Difference } \\
\text { Increase in Leaflet } \\
\text { Length }\end{array}$ & of Grand Mean) \\
\hline L1 & $8.09 \mathrm{~mm}^{\mathrm{a}}$ & 16 & $35.9 \%$ \\
L4 & $10.81 \mathrm{~mm}^{\mathrm{a}}$ & 44 & $8.0 \%$ \\
L7 & $13.05 \mathrm{~mm}^{\mathrm{a}}$ & 40 & $7.1 \%$
\end{tabular}

${ }^{2}$ No statistically significant difference from the control at $P=0.05$.

\section{Palisade Mesophyll Cell Heights}

The palisade cell heights of peeled and intact leaflets from $L 1, L 4$, and $L 7$ were measured and compared by Nested (Heirarchical) ANOVA tests (Table 2). No significant 
difference was found between the mean heights of palisade cells underlying a peel and control palisade cells.

Table 2. Grand mean of Arg leaflet palisade mesophyll cell heights and minimum detectable differences, based on nested (hierarchical) ANOVA's.

\begin{tabular}{lcccc} 
& $\begin{array}{c}\text { Grand Mean } \\
\text { Palisade Cell } \\
\text { Height }\end{array}$ & $\begin{array}{c}\text { Number } \\
\text { of Leaflets } \\
\text { Sampled }\end{array}$ & $\begin{array}{c}\text { Total } \\
\text { Cells } \\
\text { Measured }\end{array}$ & $\begin{array}{c}\text { Minimum Detectable } \\
\text { Difference } \\
\text { (\% of Grand Mean) }\end{array}$ \\
\hline L1 & $45.1 \mu \mathrm{m}^{2}$ & 12 & 540 & $17.9 \%$ \\
L4 & $39.6 \mu \mathrm{m}^{\mathrm{a}}$ & 10 & 450 & $21.7 \%$ \\
L7 & $42.9 \mu \mathrm{m}^{\mathrm{a}}$ & 12 & 540 & $16.3 \%$
\end{tabular}

${ }^{\mathrm{a}}$ No statistically significant difference from the control at $P=0.05$. 
Figs. 5-14. SEM and transverse sections of leaflets of $P$. sativum var. argenteum. $E=$ unpeeled adaxial epidermis. 5, 6. Wound response tissue that formed when leaflets were peeled on Day 1 and subjected to desiccating conditions (outside of humidity chambers) until Day 11 . The wound response ranged from abnormal cell elongation to complete cellular collapse in the exposed palisade mesophyll. 5. L1 wound tissue typical of abnormal cell elongation. X311. Bar $=50 \mu \mathrm{m} .6$. L7 wound tissue typical of complete cellular collapse. X778. Bar $=20 \mu \mathrm{m} .7-12$. Transverse sections of immature leaflets. The differentiation of the mesophyll cells has not yet produced the size, shape, vacuolation, and intercellular space system to clearly distinguish the palisade and spongy tissues. Leaflet thickness diminishes from $L I$ to $L 7$. X149. Bar $=100 \mu \mathrm{m} .7$ - 9. Immature, intact leaflets of $L 1, L 4$, and L7, respectively, fixed on Day 1. 10-12. Immature leaflets of L1, L4, and L7, respectively, peeled on Day 1 and immediately fixed. The mesophyll underlying the peel shows no evidence of mechanical damage or wound reaction. 13, 14. Scanning electron micrographs of immature leaflets of $L 1$ and $L 7$, respectively, peeled and immediately fixed on Day 1 . The palisade cells underlying the peel are tightly packed and fully turgid. Recent or ongoing anticlinal cell divisions are frequent (unlabeled arrows). Small tissue caps (TC), apparently remnants of cell wall material torn from the peeled epidermis, are evident. The appearance of the epidermis is altered by the presence of an underlying vein $(V)$ in Fig. 13. X311. Bar $=50 \mu \mathrm{m}$. 

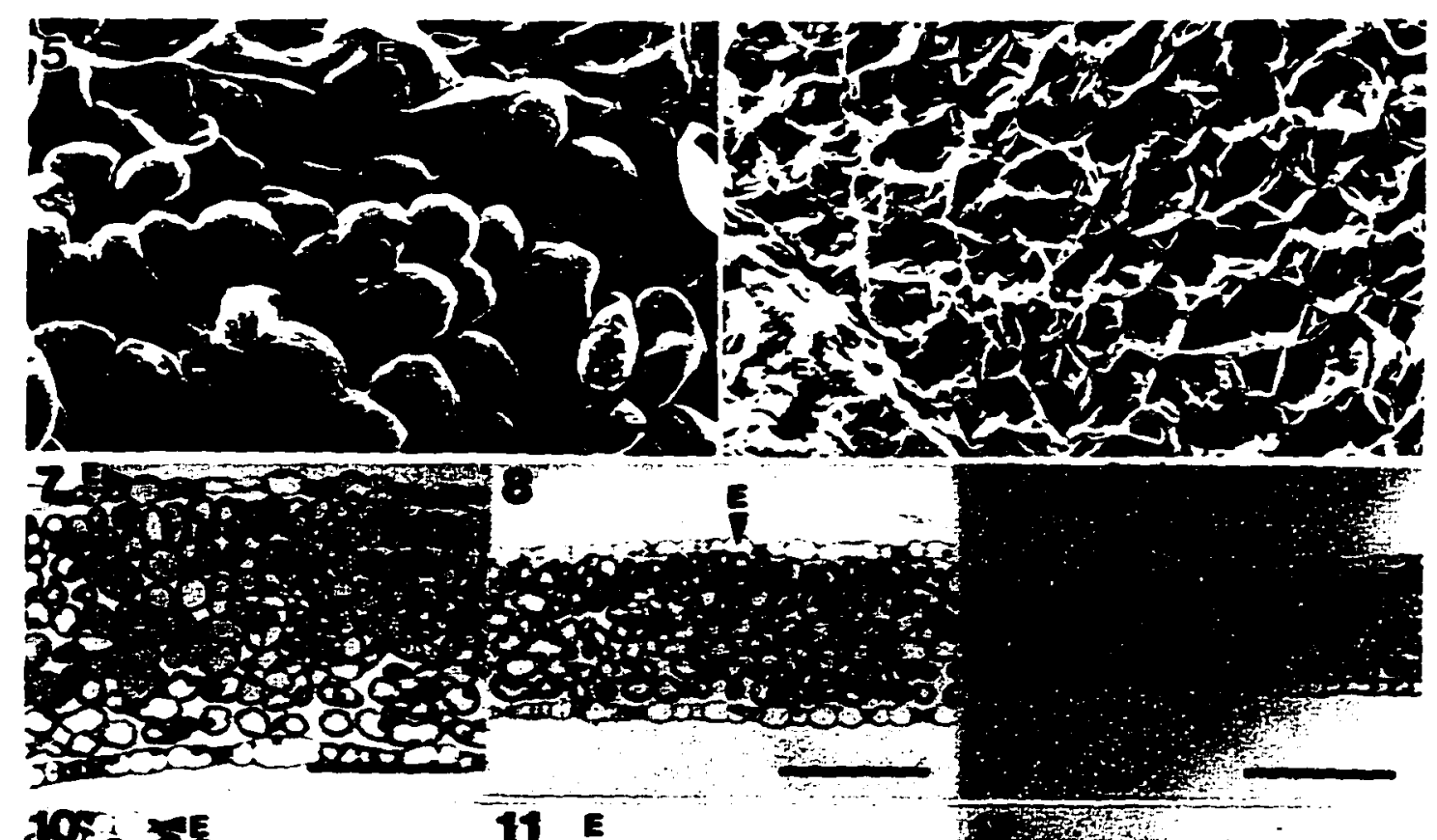
Aqu

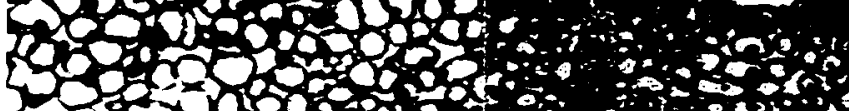

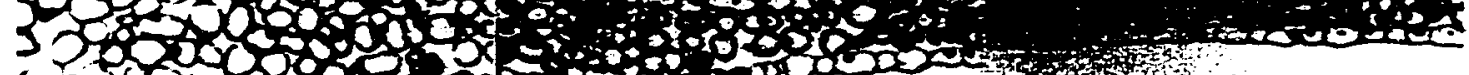

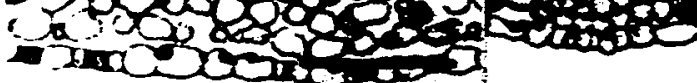

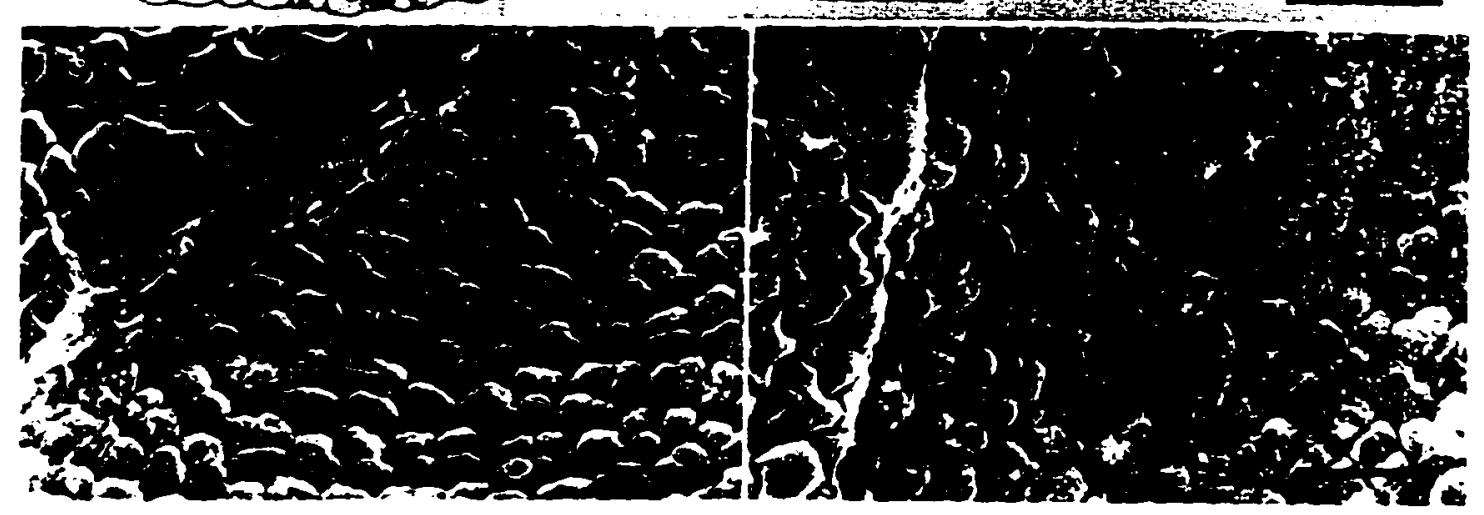


Figs. 15-20. Transverse sections of mature Arg leaflets. $E=$ adaxial epidermis. X149. $B a r=100 \mu \mathrm{m}$. 15-17. Intact leaflets of L1, L4, and L7, respectively, grown in humidity chambers from Day 1 to Day 11 . Regional differentiation of the mostly single-layered palisade mesophyll (PM) and multilayered spongy mesophyll (SM) has occurred. The palisade cells have enlarged and attained a more cylindrical or oval shape, while the spongy cells have enlarged and become irregular in shape. An extensive intercellular space network is evident. Note the poor epidermismesophyll adhesion, which defines the phenotype of the Arg mutant. 18-20. Leaflets of L1, L4, and L7, respectively, peeled on Day 1 and grown in humidity chambers until Day 11. The anatomy is indistinguishable from that of the unpeeled leaflets above. 


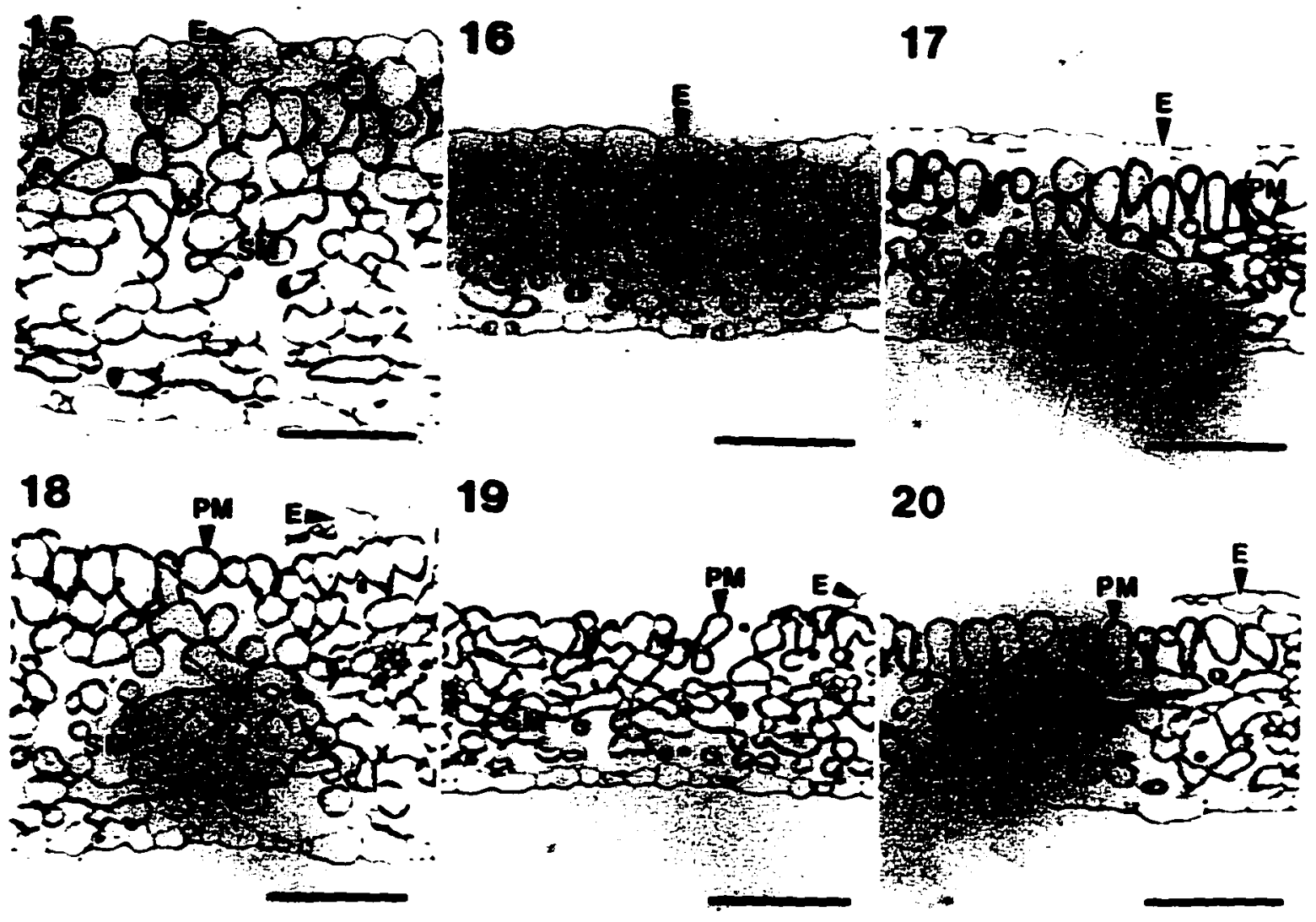


Figs. 21-26. Scanning electron micrographs of mature Arg leaflets grown in humidity chambers from Day 1-11. The dimpled appearance of the palisade cells is due to the presence of chloroplasts. Tissue caps (TC) are present on the outer tangential wall of some of the palisade cells. The unpeeled adaxial epidermis $(E)$ adjacent to the peeled region is included in each micrograph. $S=$ stoma. $X 311 . \mathrm{Bar}=50$ $\mu \mathrm{m} .21,23,25$. Control leaflets of $L 1, L 4$, and $L 7$, respectively, grown unpeeled until the end of the experimental period. The leaflets were peeled subsequently to visualize the palisade cells with the SEM. 22, 24, 26. Leaflets of $L 1, L 4$, and $L 7$, respectively, peeled on Day 1 and fixed on Day 11 . The majority of the palisade cells show the same size, shape, and spacing as in the controls. In Fig. 22, a short row of abnormal elongated cells (EC) has developed on the border of the peeled region. 


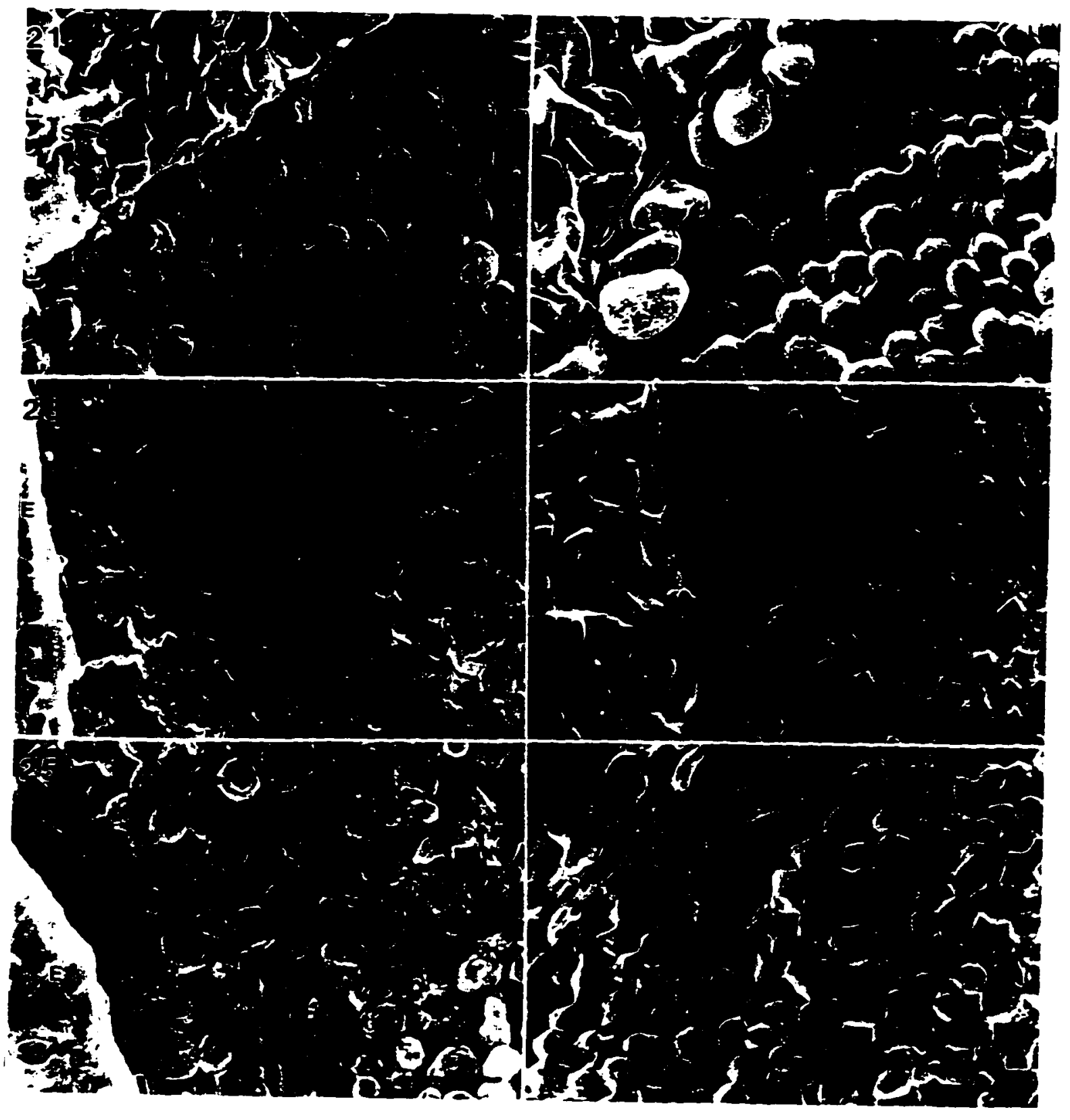




\section{Discussion}

If the epidermis controls the development of leaf morphology and histology by exerting pressure on underlying tissues (Sachs, 1865; Kutschera et al., 1987; Kutschera and Briggs. 1987. 1988; Kutschera. 1992), peeling leaves early in ontogeny before a coordinated cell division stage might well be expected to affect the development of the proper number of mesophyll cell layers. By the same token, relieving epidermal pressure by peeling at an early stage could also affect the ultimate size attained by internal (mesophyll) cells if cell expansion were constrained by epidermal compression. In this study, Arg leaflets were peeled at an early stage before completion of cell expansion and. in some cases, before establishment of the number of cell layers characteristic of the mature leaflet. This work thus constitutes a reasonable test of the operation of epidermal pressureinduced histogenetic and morphogenetic mechanisms.

The results of this study indicated that normal leaflet development was unchanged by epidermal excision. Localized pressure of the epidermis had no effect on leaflet size and shape or on the layering patterns and size of interior cells. Therefore, there was no evidence discovered for an epidermal influence on overall leaf growth, morphogenesis, or histogenesis. This result is not surprising in light of the weak contact between the epidermis and mesophyll in Arg organs. Despite the apparently reduced epidermal pressure, the leaflets grow and develop with no discernible difference from wild type garden pea leaflets. The parameters examined herein appear to be controlled genetically or by cellular interactions not involving the epidermis. These parameters may be determined early in leaf ontogeny, soon after leaf initiation, with continuing cell divisions in the epidermis necessary only to proper expansion of the leaf (Foard, 1971).

Peeling-induced cell division and cell expansion, typical of wound reactions, did not occur in the Arg leaflets. Thus there was no danger of confusing these phenomena with similar ones that might have been associated with pressure relief. The small tissue caps 
observed on the outer tangential wall of the palisade cells following peeling were not produced by an active wound response, as they occurred on all peeled leaflets, including (and more frequently in) those peeled on Day 11 and immediately fixed. These caps were apparently remnants of walls torn from the epidermis when it was removed. While not forming wound repair tissue in response to peeling when maturation occurs in high humidity, the Arg mutant was capable of producing wound tissue, as shown by peeled leaflets left to mature in a dry environment. The wound tissue was composed of thin. brittle layers of collapsed cells in some areas and, in others, of greatly enlarged cells that could not be mistaken for normal palisade mesophyll. Cell divisions and normal cell growth contributing to the expansion of the peeled areas in conjunction with the expansion of the rest of the leaflet lamellae were observed, demonstrating cell viability and continued capacity for growth and division in peeled leaflets. Thus the lack of supernormal cell expansion and division in peeled regions of leaflets grown in high humidity was not the result of wound-induced death or cell impairment. The Arg mutant might prove valuable in other studies in which access to internal tissues or epidermal removal without an appreciable wound response is desired.

It should be pointed out that small differences in cell height between treatments were not detectable by the methods used in this investigation. Given the variability of palisade mesophyll cell orientation within a single leaflet and the fact that leaflets were rarely flat, median sections through each cell were not possible. Slight obliquity of the sections would result in over-or underestimates of cell lengths, although the method was the same for all treatments and controls. The statistical tests used produced somewhat large minimal detectable differences so that a finding of a lack of statistically significant difference was within a relatively large range. Thus, while the epidermis had little effect on restraining underlying cell growth, it could not be concluded that there was no effect whatsoever. Nonetheless, if epidermal pressure is a significant factor in determining underlying cell 
organization, in inhibiting or promoting cell division, in restraining cell expansion, and in overall leaf size and shape, large changes would be expected in these parameters after peeling.

Lintilhac and Vesecky (1981) applied external compression to a stem for 24 hours. then released the pressure and allowed the stem to grow for 21 days. Periclinal cell divisions increased beneath the compressed area. During the 21 days after release, these newly formed cells expanded, raising the compressed area above the rest of the epidermal surface. The Arg leaflets in this study, when released from epidermal pressure by peeling. did not display any reduction in the numbers of cell layers, as might be expected if epidermal pressure stimulates or induces subepidermal periclinal cell division. Nor did they display any increase in cell layers, as would occur in the formation of callus-like tissue or wound periderm. The magnitude of the compressive force of the epidermis is sufficiently lower than that produced by Lintilhac and Vesecky's clamping device for epidermal compression to be inconsequential to the induction of cell division. It is also possible that the initiation of cell divisions in Lintilhac and Vesecky's work was due to a wound response to damage caused to the superficial cell layers of the stem by the clamping device. Oriented cell divisions associated with organogenesis in this study are not generated by epidermal compression and do not themselves bring about organogenesis but rather are the result of plant growth and organogenesis that require cell division for partitioning the internal tissues (Kaplan and Hagemann, 1991; Cooke and Lu, 1992). In this case, the orientation of the plane of cell division presumably results from stresses intrinsic to the internal tissues (Lintilhac and Vesecky, 1980; Lynch and Lintilhac, 1997). 


\section{Literature Cited}

AKED, J., AND J. L. HALL. 1992. The uptake of glucose, fructose and sucrose into the lower epidermis of leaf discs of pea (Pisum sativum L. cv. Argenteum). New' Phytologist 123: 271-278.

BROS, W. E. AND B. C. COWELL. 1987. Graphical method for optimum precision (sample size). Journal of Experimental Marine Biology and Ecology 114: 63-71.

COOKE, T. J., AND B. LU. 1992. The independence of cell shape and overall form in multicellular algae and land plants: cells do not act as building blocks for constructing plant organs. International Joumal of Plant Science 153: S7-S27.

COSGROVE, D. 1986. Biophysical control of plant cell growth. Annual Review of Plant Physiology 37: 377-405.

FOARD, D. E. 1971. The initial protrusion of a leaf primordium can form without concurrent periclinal cell divisions. Canadian Journal of Botany 49: 1601-1603.

GOLdBERG, R. B., G. DE PAIVA, AND R. YADEGARI. 1994. Plant embryogenesis; zygote to seed. Science 266: 605-614.

HOCH, H. C., C. PRATT, AND G. A. MARX. 1980. Subepidermal air spaces: basis for the phenotypic expression of the Argenteum mutant of Pisum. American Journal of Botany 67: 905-911.

HUMPHREY, C. D., AND F. E. PITTMAN. 1974. A simple methylene blue-azure II-basic fuchsin stain for epoxy-embedded tissue sections. Stain Technology 49: 9-14.

JEWER, P. C., L. D. INCOLL, AND J. SHAW. 1982. Stomatal responses of Argenteum - a mutant of Pisum sativum L. with readily detachable leaf epidermis. Planta 155: 146153.

JONES, A. M. 1994. Auxin-binding proteins. Annual Review of Plant Physiology and Plant Molecular Biology 45: 393-420.

KAPLAN, D. R., AND W. HAGEMANN. 1991. The relationship of cell and organism in vascular plants. Are cells the building blocks of plant form? Bioscience 41: 692703.

KUTSCHERA, U. 1992. The role of the epidermis in the control of elongation growth in stems and coleoptiles. Botanica Acta 105: 246-252.

R. BERGFELD, P. SCHOPFER. 1987. Cooperation of epidermis and inner tissues in auxin-mediated growth of maize coleoptiles. Planta 170: 168-180.

AND W. R. BRIGGS. 1987. Differential effect of auxin on in vivo extensibility of cortical cylinder and epidermis in pea internodes. Plant Physiology 84: 13611366. 
- . 1988 . Interaction between cortical cylinder and epidermis during auxin-mediated growth in pea internodes. Plant Science 54: 23-28.

LINTILHAC, P. M., AND T. B. VESECKY. 1980. Mechanical stress and cell wall orientation in plants. I. Photoelastic derivation of principal stresses with a discussion of the concept of axillarity and the significance of the "arcuate shell zone." American Journal of Botany 67: 1477-1483.

, AND - 1981. Mechanical stress and cell wall orientation in plants. II. The application of controlled directional stress to growing plants; with a discussion on the nature of the wound reaction. American Journal of Botany 68: 1222-1230.

LYNCH, T. M., AND P. M. LINTHLHAC. 1997. Mechanical signals in plant development: a new method for single cell studies. Developmental Biology 181: 246-256.

MASUDA, Y., AND R. YAMAMOTO. 1972. Control of auxin-induced stem elongation by the epidermis. Physiologia Plantarum 27: 109-115.

MARX, G. A. 1978. Argenteum: a mutant under nuclear and extranuclear control. Pisum Newsletter 10: 34-37.

NAPIER, R. M., AND M. A. VENIS. 1990. Receptors for plant growth regulators: recent advances. Journal of Plant Growth Regulation 9: 113-126.

SACHS, J. 1865. Handbuch der Experimental-Physiologie der Pflanzen. Engelmann, Leipzig.

SPURR, A. R. 1969. A low-viscosity epoxy resin embedding medium for electron microscopy. Journal of Ultrastructure Research 26: 31-43.

THIMANN, K. V., AND C. SCHNEIDER. 1938. Differential growth in plant tissues. American Journal of Botany 25: 627-640.

VAN OVERBEEK, J., AND F. W. WENT. 1937. Mechanism and quantitative application of the pea test. Botanical Gazette 99: 22-41.

VAN Volkenburgh, E., AND R. E. Cleland. 1981. Control of light-induced bean leaf expansion: role of osmotic potential, wall yield stress and hydraulic conductivity. Planta 153: 572-577.

ZAR, J. H. 1984. Biostatistical Analysis, 2nd ed. Prentice Hall, Englewood Cliffs, New Jersey. 


\section{Appendix 1. Preliminary Operations}

\section{Studies of Plant Growth and Seed Production}

Several factors affecting plant growth and seed production were tested. The soil, container size, time of year, and environment (growth chamber $v s$. field conditions) in which the plants were grown all influenced plant size, generation time and seed production.

Soil. Soil mixes were tested by planting eight seeds in 1-gallon pots filled with either the soil mix used in the SJSU greenhouses (greenhouse soil mix) or Supersoil $®$ fortified with Nutricote ${ }^{\circledR}$ (Supersoil mix). These plants were started in October, 1992. grown on the roof of Duncan Hall, and harvested in March and April, 1993. The plants grown in the Supersoil mix produced 16 seeds per plant compared to only 5 seeds per plant grown in the greenhouse soil mix. The $\mathrm{pH}$ of the Supersoil mix was 7. The $\mathrm{pH}$ of the greenhouse mix was 5. This acidity was the probable cause for the reduced plant productivity in the greenhouse soil mix.

Container size $v s$. season. Container size was compared by planting eight seeds per pot in I-gallon or in 3-gallon pots filled with the Supersoil mix. The plants grew on the roof of Duncan Hall until seed was harvested. When tendrils formed, 12-inch tall cylinders made of plastic-coated fencing were pushed into each pot to provide support. Plants grown in 3-gallon pots produced 20 seeds per plant, nearly four seeds more per plant than plants grown in 1-gallon pots. The planting dates, however, differed for these two conditions. The 1-gallon pots were planted in October, 1992. The 3-gallon pots were planted in January, 1993. Because peas are a cool weather crop, the greater seed production of the January crop may have resulted from seasonal conditions in addition to larger pot size.

Outdoors vs. growth chambers. Whether plants were grown outdoors or in growth chambers also affected maturation time and seed production. Twelve plants planted six inches apart in late October, 1992, in an outdoor raised bed filled with native soil (black, clayey), steer manure, and compost averaged ca. 4 feet in height (taller than those 
grown in pots outdoors or in growth chambers) and produced the most seeds per plant. Twenty pods per plant were harvested, averaging 6 peas per pod. Generation time was long in plants grown outdoors, ranging from $31 / 2$ months for plants sown in January and harvested in April or May to 6 months for plants sown in October and harvested in April.

The selected growth chamber conditions were 16 hours of light and temperatures of $15^{\circ} \mathrm{C}$ at night and $20^{\circ} \mathrm{C}$ during the day. A red-to-far red wavelength ratio close to 1 , measured with a $\mathrm{Li}$-Cor light meter, was found to be necessary to achieve simultaneous germination of each batch of seeds. Plants were grown one per pot in 4-inch pots in growth chambers. The epicotyl hooks appeared within 1 to 2 days of each other and approximately 6 days after planting. The plastochron length for the formation of the subsequent leaves averaged $c a .3$ days. The average age of the seedlings when $L 1$ (the first leaf produced by the seedling) was at the proper stage for peeling was 8.6 days after planting: it was 16.6 days after planting for $L 4$ and 25.5 days after planting for $L 7$. The leaf size of plants grown in the growth chamber was comparable to that of plants grown outdoors for the nodes studied herein. Rarely were more than three pods per plant produced, each pod containing 3-4 peas. This method of seed production was used during the summer when the plants fared poorly outdoors.

Even in the growth chambers, the plants appeared to be subtly influenced by the season. Germination was more nearly simultaneous, the plastochron length was slightly shorter, and the leaves appeared to be grayer and larger in the late fall, winter, and early spring than was the case during the summer. Despite this variation, the plants used for the experiments were grown in the growth chambers because the patterns of plant growth were more consistent throughout the year than under outdoor conditions. 


\section{Studies of Peeling Conditions}

Methods of removing the epidermis from the leaflets without wounding the leaflet had to be developed at the onset of this work. Desiccation might trigger a wound response in exposed palisade cells so peeling in air vs. under water was tested. Tearing of palisade cells during peeling might also trigger a wound response so the presence of mechanical damage after peeling was also investigated.

Peeling in air vs. water. The SEM was used to compare the effects of peeling in air vs. peeling under water on the development of a wound response. $\mathrm{L} 1, \mathrm{~L} 4$, and L7 specimens were peeled in situ while submerged in water or in air. Half were fixed immediately after peeling and half after 7 days of growth in humidity chambers. No differences in cell size, shape, wound reactions, or overall leaf morphology were detected between leaflets peeled in air or under water. Visibility was very poor when leaves were underwater; therefore, experimental leaflets in this study were peeled in air.

Mechanical damage. Specimens that had been peeled at young stages (Day 1) or at maturity (Day 8 or 11) were examined by SEM for the presence of ruptured or otherwise damaged palisade cells. Micrographs were taken at a magnification of $400 X$, covering 100 to 200 palisade cells per specimen.

Of 18 specimens that were peeled on Day 1, no ruptured palisade cells were found. However, ruptured palisade cells (three or fewer ruptured cells out of 100-200 cells per specimen) were observed in four of 12 specimens peeled on Day 8 or 11 . It is impossible to know whether the damage was the result of epidermal removal or of the fixation and SEM preparation processes.

Tissue caps, flattened or shallow cup-like structures, were noted on the outer tangential walls of some palisade cells in every specimen examined. These caps appear to be contact points between the epidermis and the palisade cells where epidermal cells left behind 
impressions and even, in many cases, remnants of cell-wall material. Tissue caps were found in greater numbers in mature specimens than in immature (Table 3).

Table 3. The incidence of tissue caps seen in scanning electron micrographs of $\mathrm{Arg}$ leaflets from which epidermis was peeled at Day 1 or Days 8 or 11 .

\begin{tabular}{|c|c|c|c|c|}
\hline $\begin{array}{l}\text { Specimen Stage } \\
\text { at Fixation }\end{array}$ & $\begin{array}{l}\text { Number of } \\
\text { Specimens } \\
\text { Examined }\end{array}$ & $\begin{array}{c}\text { Total } \\
\text { Cells } \\
\text { Counted }\end{array}$ & $\begin{array}{l}\text { Mean Number } \\
\text { of Caps per } \\
\text { Specimen }\end{array}$ & $\begin{array}{l}\text { Mean Number } \\
\text { of Cells per Cap }\end{array}$ \\
\hline Immature $^{a}$ & 5 & 1006 & 4.0 & 62.9 \\
\hline Mature $^{b}$ & 7 & 572 & 2.1 & 38.0 \\
\hline Mature $^{c}$ & 7 & 677 & 13.9 & 6.9 \\
\hline Mature $^{d}$ & 3 & 166 & 6.6 & 8.3 \\
\hline \multicolumn{5}{|c|}{$\begin{array}{l}{ }^{2} \text { Peeled Day } 1 \text {, fixed Day } 1 \\
\text { bPeeled Day } 1 \text {, fixed Day } 11 \text {, grown in humidity chambers } \\
\text { cPeeled Day } 11 \text {, fixed Day } 11 \text {, grown in humidity chambers } \\
\text { dPeeled Day } 11 \text {, fixed Day } 11 \text {, grown without humidity chan }\end{array}$} \\
\hline
\end{tabular}

\section{Study to Determine the Experimental Period}

To see the maximum effect of peeling, it was vital that the experimental specimens reached full maturity. To determine the length of time needed for the leaves to reach maturity after peeling, the growth curves for $\mathrm{L} 1$ and $\mathrm{L} 7$ were plotted. The lengths of the midribs of the right, or experimental, leaflets and the left, or control, leaflets were measured daily as were the widths of the outside halves, or Side $b$, of these leaflets with dial calipers (Mitutogo) (Fig. 27). The point at which the growth curves became level, indicating the end of leaflet growth, was used as the indicator of internal maturity (Figs. 28,29 ). The experimental period was set at ten days, the time at which all leaves had reached full laminar expansion. 


\section{Studies to Maintain Humidity around Peeled Leaflets}

Several methods for maintaining humidity over the area of the peel were tried before a satisfactory procedure was invented.

Plastic bags. Small plastic bags were tied over treated leaves. High humidity was maintained within the bags, but it proved to be impossible to keep the expanding leaves from becoming distorted by contact with the plastic bags.

Lanolin. When lanolin was applied to a peeled area to protect it from desiccation, a wet, yellow-brown area developed beneath the lanolin. Whether this abnormal area was the result of tissue death or of bacterial or fungal disease was not explored.

Cover glasses. A fragment of a cover glass was placed over each peeled area and sealed in place with a bead of lanolin that touched only the epidermis around the peeled area. Humidity was lost when some cover slips were displaced from the leaflets as the leaflets flexed during expansion. Where the cover slips remained attached, the entire leaf surface under the cover slip again developed a yellow-brown, wet appearance.

Humidity chambers. Humidity chambers developed from petri dishes proved to be satisfactory. Humidity was maintained during the experimental period. However, one quarter to one half of the leaves enclosed in humidity chambers on Day 1 were excluded from the study by Day 11 , because one or both leaflets became distorted by prolonged contact with the humidity chamber walls. 


\section{Appendix 2. Seed-Production Procedures}

Three methods of producing seed of Pisum sativum var. argenteum were used. In the first, seeds were planted outdoors in a $4 \mathrm{ft} . \times 8 \mathrm{ft}$. 10 in. raised bed in Palo Alto, California between October and March. The soil in each bed was prepared by adding one bag each of steer manure and compost. The seeds were planted 4-6 inches apart in rows spaced every 8 inches. Planting depth was 1-2 inches. Seed was also obtained from plants started in 4-inch pots at SJSU and transplanted to the raised beds in Palo Alto.

The second method produced seed by growing 8 plants per pot in 3-gallon pots in the open area adjacent to the greenhouses on the roof of Duncan Hall, SJSU. In this case, the seeds were planted 1 inch deep. The pots were watered, covered with glass, and set on pallets in partial sun. After germination, the glass was removed and the pots were watered biweekly.

The third method to produce seed utilized the plants grown for experimental purposes in the growth chambers at SJSU. After the treated leaves were harvested, the plants were returned to the growth chambers to flower and produce seed. Senescing plants were removed from the growth chambers to prevent spread of disease and hung indoors to dry. Growth chamber conditions and preparation of seed and soil for planting in pots at SJSU were as described in Appendix 3.

After the plants began senescing in response to the ripening of the pods, water was withheld both for outdoor and for growth-chamber-reared plants. The dead plants were cut or pulled up and hung to dry further until the pods were dry enough to rattle but not so dry that they split open spontaneously. The pods were shelled and the peas dried further, if necessary, and then stored in paper bags. 


\section{Appendix 3. Growth-Chamber-Cultivation Procedures}

Seeds were soaked for 5-10 minutes in 10\% bleach, then rinsed with tap water immediately prior to planting. The potting soil consisted of Supersoil® potting soil enriched with Nutricote $®$ pellet fertilizer. One lb $(2.2 \mathrm{~kg})$ of Nutricote ${ }^{\circledR}$ Type 360 was mixed with one 2-cu-ft bag of Supersoil $B$. When Nutricote $\&$ Type 100 was used, $300 \mathrm{~g}$ was mixed with 2-cu-ft of Supersoil@. Four-inch square pots were filled with the soil mix. For each filled pot, one rinsed seed was placed in a half-inch-deep hole in the middle and covered. The whole pot was placed in a small plastic bag to catch run-off. It was watered and placed in a Convirons $\otimes$ growth chamber. Gaps were left between the pots for air circulation. The soil was kept moist throughout the growing period.

Up to 50 planted pots were placed in a growth chamber at full fluorescent illumination and half to full incandescent illumination, using 60-watt light bulbs. A 1:1 ratio of red to far red wavelengths was obtained by manipulating the number and age of the incandescent bulbs used. Older light bulbs produced more red light relative to far red than newer bulbs. Humidity was not controllable in these growth chambers, but 1-3 one-inch diameter holes in the front walls of the chambers permitted some exchange with the air in the room. A photoperiod of 16 hours was established. Night and day temperatures were set at $15^{\circ} \mathrm{C}$ and $20^{\circ} \mathrm{C}$, respectively.

When plants developed tendrils that actively twined, usually in the fourth leaf, bamboo stakes were pushed into the pots to provide support and to stabilize the plants against further movement that could affect the position of treated leaves within their humidity chambers. 


\section{Appendix 4. Peeling Procedures}

Peeling in situ. After the midrib length and the width of side $b$ (Fig. 27) of each of the basal leaflets were measured with Mitutogo dial calipers, the plant in its pot was placed in a cut-out beneath a dissecting microscope. The plant was lowered or raised until the leaflets could be bent over a dissecting dish made by filling a syracuse dish with melted dental wax. Insect pins were used to prop the leaf without piercing any parts in position with the $b$ side of the experimental leaflet on the bottom against the wax and the control leaflet pulled to one side to expose the experimental leaflet. The $a$ side of the experimental leaflet was lifted from the $b$ side with jeweler's forceps and held open with a damp cottontipped applicator stick. One tip of the forceps was slid under a portion of epidermis lying over the midrib in the middle third of the leaflet. A bit of epidermis was lifted by the forceps and peeled away towards the margin of the $b$ side of the leaflet (Fig. 30). The pins were removed and the leaflets re-folded, returned to their original positions, and enclosed in a humidity chamber.

Peeling and immediate fixation. The petiole of a leaf to be peeled and fixed immediately was cut close to the leaf. The leaf was placed on a small pool (2-3 drops) of $2 \%$ glutaraldehyde in sodium cacodylate buffer in a dissecting dish so that the cut stem was submerged in the fixative. The dish was then placed under a dissecting microscope. Insect pins were used to open the leaflets and hold them steady while epidermis was removed as described above. Once the epidermis was removed, the peeled regions of the leaflets no longer repelled liquids and sank into the glutaraldehyde. SEM and LM specimens were then excised with a scalpel blade, transferred to vials of glutaraldehyde, and prepared for LM and SEM viewing. 


\section{Appendix 5. Palisade cell height measurements using JAVA}

Jandel Video Analysis Hardware (JAVA) Version 1.40 (Corte Madera, CA) was used for measuring distances and stain intensities at the microscopic level. The JAVA software was mounted on a Compudyne PC-clone model number 3DX/33 with an Intel 32-bit processor. An Olympus BH microscope, on which a Pulnix video microscope camera TM7CN (Sunnyvale, California) was mounted provided the visual input. The microscope image was displayed on a Panasonic TR-124 MA video monitor.

\section{Directions for Using JAVA to Measure Palisade Cell Height}

JAVA is designed with four menu screens, each of which performs a specific function. "Morph" is the general manager and enables the measurements to be made. "Inten" captures the video image, while "Disc" provides access to other JAVA files and saves and prints files. "Data" contains the spreadsheet and statistics package.

Prompts and menu selections seen on the monitor are enclosed in quotation marks. The user's responses are italicized. Non-italicized punctuation marks belong to the sentence, not to the response. Pressing the Enter (or Return) key is indicated by these two marks, $\diamond$. To select a menu item, position the cursor on the desired menu item, then click once and release the left mouse button.

1. Turn on the power to the microscope, video monitor, computer, and printer at the two power-strip switches. Do not turn any of the equipment on or off individually. Place a slide on the microscope stage, switch to the $40 \mathrm{X}$ objective lens, and adjust the light intensity and focus with the microscope controls.

2. To start JAVA, enter the password when the Windows prompt appears on the PC screen. Then press Enter.

3. The Windows 3.1 screen and menu appear. Select Program Manager, click on File, then on Exit Windows. 
4. The Dos prompt, "c:I," will appear. Type the word java then $\diamond$. The video screen will light up and the morph menu bar will appear on the computer monitor. The name of the menu appears below the menu bar found on the right side of the screen.

If data from a previous session were not cleared, the prompt "Save data?" will appear at the bottom of a box. Respond with $N$, then proceed to step 5 . If this prompt does not appear, proceed directly to step 5.

5. Click on inten. When the intensity menu bar appears, click on freeze. At this point, the video screen will show the image projected from the microscope. If no image can be discerned. adjust the monitor light level using the Pulnix switch hanging from the video camera. There are two buttons on the bottom of the switch separated by a display showing the light level. Click one or the other button to increase or decrease the light level on the monitor until the image can been seen. Do not attempt to adjust the monitor light level by changing the microscope light level. While watching the monitor image, use the controls on the microscope to fine tune the focus. Readjust the monitor light level if necessary, again using the Pulnix switch. The orientation of the section on the monitor may be changed by carefully turning the video camera until the preferred orientation is displayed on the monitor. When the monitor image is well focused and sufficiently bright, click on freeze again. This will capture the image and allow you to draw on the monitor image using the mouse. The microscope controls will move the slide at this point, but this movement will no longer affect the image frozen on the monitor.

6. Return to the morph menu by clicking once on morph. To start a session, select the type of measurement you want. To measure a distance between two points, click on dist and select the calibration file you need by clicking on disk. The disk menu will appear. From the bar on the right, click on calib. A list of calibration files will appear. Click on $40 X$ to select the calibration necessary when using the $40 \mathrm{X}$ microscope objective and press $\diamond$. A brown box will appear on the screen containing the prompt, "Do you want to 
override the calibrations currently in effect? YES NO" Click on YES, then click on the esc morph button in the upper right hand corner of the screen to return to the morph menu. This procedure establishes that the measurements will be the proper scale for an image viewed through the $40 \mathrm{X}$ objective. See step 15 for directions to make a calibration file for use with a different magnification.

7. The cursor should now look like an "X." If it looks like a "!," it is positioned over a menu bar hidden by the cell image. Click the right mouse button once to hide the menu bar. The cursor should revert to the "X." To measure the height of a palisade cell, position the "X" at the middle of the top wall and click the left mouse button once. Move the cursor to the middle of the bottom of the cell wall, thus drawing a line, and click the left button once to end the line. Click the right mouse button to send the data to the spread sheet. Repeat this combination for each cell height measured.

8. When all the cells on the screen have been measured and you wish to move to new cells, select Inten (intensity menu), then click on freeze, thus de-selecting freeze. You may now move to another portion of the slide or replace the slide with another with the microscope controls. The monitor image will reflect the changes as you make them. Adjust the focus and light intensity if necessary, as in step 5. Select freeze again, return to the morph menu by clicking on morph. then repeat step 7. Steps $1-4$ and 6 must be repeated only to start a measuring session.

9. When you have finished measuring, remain in the morph menu and click on "data." The spreadsheet will appear so you may check it to be sure the desired number of cells has been counted and recorded. Check any duplicated cell heights to see if they bracket a move from one screenful of cells to another. If so, check whether the two cells really are identical in height or whether one cell has been measured twice. One of the duplicates may be deleted following the directions in step 10.

10. Manipulating the spreadsheet. 
A. Click on Show data. Scroll bars with arrows will appear on the top and sides of the spreadsheet. Click on the arrows to move through the spreadsheet.

B. Delete data from one cell by clicking Clear Block. A small box will appear at the upper left hand corner of the screen with the word "row" at the bottom of it. Type in the row number of the cell to be deleted, then $\diamond$. The box will display "column." Type in the column number, then $\diamond$. The cell to be deleted will be highlighted. Press $\diamond$ once more and the data will be deleted. This method can also be used to delete the data from several cells at once as long as they are adjacent and form a square or rectangle. Type the row number of the first datum, then $\varnothing$, then type the column number of the last datum. then $\diamond$. In this case, a second $\diamond$ after the column number is not necessary.

Return to the frozen image to measure more cells if necessary by clicking on the esc morph button and repeating step 7. Before measuring cells from a new section, you must save and print out the data just collected.

11. To save and print the data for one section, three sections are measured for each leaf. return to the morph menu by clicking on esc morph. In the morph menu, click disk. The disk menu will appear.

For the first time each session, call up the proper directory by clicking on chg dr pa. A list of directories will appear. Click on Mary_Asc.

Click on Asc data, then to disk. Another box will appear. Click on .PRN in this box, then press $\diamond$.

When the file-name block appears, type the name, then press $\diamond$. These files are named after the slide holding the cells measured. A, B or C is added to the slide name to indicate first, second, and third section measured. For example, for height measurements from the first section from slide $3 \mathrm{C} 1 \mathrm{~B} 4$, the name would be $3 \mathrm{C} 1 \mathrm{~B} 4 \mathrm{~A}$. For width measurements, 3C1B4AW is used. In some cases, some control leaves were not peeled prior to fixation, while other control leaves were peeled prior to fixation. In these cases, $N$ 
for "not peeled" or $P$ for "peeled" are added to the end of the file name before the $W$ or the section-indicating letter.

12. There is no way to transfer this data out of JAVA except to print it out and re-enter it into Excel or Systat. Select.PRT, then press return. A print box will appear with the prompt, "print options? Yes." Type $Y$ or $\diamond$. Wait for the spreadsheet to be printed out, then label it immediately with the date and the name of the slide and section it represents. 13. To measure the next section on this slide or on another slide, return to the morph menu and click on Data then select Clear spreadsheet. When you see, "Do you really want to clear all data?" type $Y$, then $\diamond$. Return to morph (esc morph) and, from morph, repeat step 5 through 12, skipping step 6 . Always clear the data between sections measured and printed out.

14. To end a session, after you have cleared the most recent spreadsheet, return to morph (esc morph). From the morph menu, click on exit.

A box will appear with the prompt "Exit? No." Type $Y$, then $\diamond$. The Dos prompt "c:/java>" will appear. At this point, turn off the equipment with the two power-strip switches and replace the microscope, computer monitor, keyboard, and printer covers. There is no cover for the video monitor connected to the microscope.

15. To make a calibration file, put the micrometer slide under the $40 \mathrm{X}$ lens. This slide is in a leather case on top of the video monitor. Select Morph. Select Dist. Select Calib. Select $F 2$ (freeze). Draw a line between 0.01 lines with the cursor, as shown below.

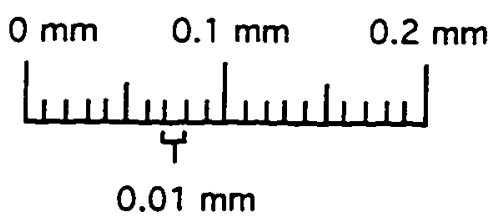


You should get a box saying 255.00000 absolute (extrapolated) and a prompt asking if you want to save this calibration file. Save the file. Return to step 6. 


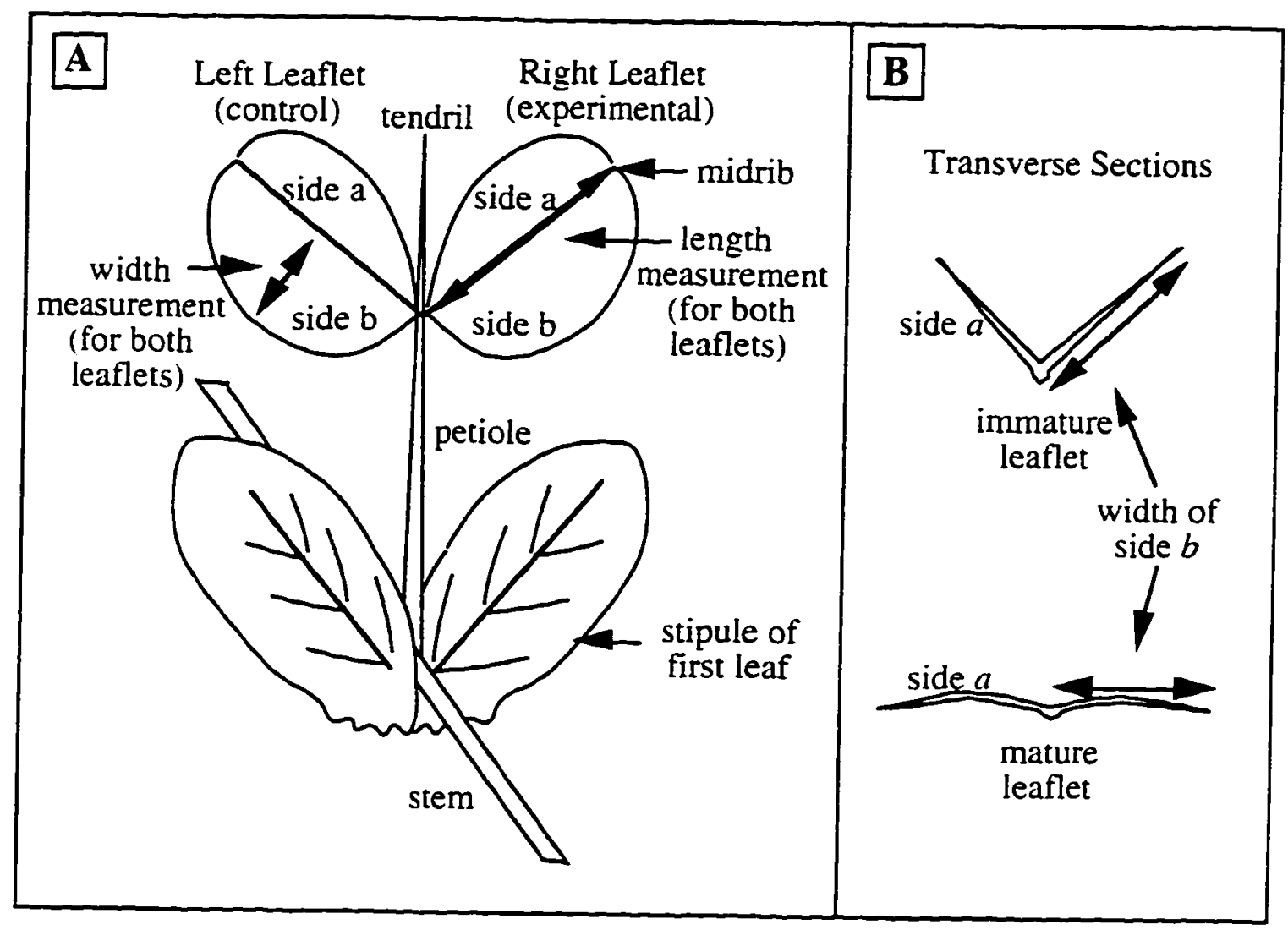

Fig. 27. Location of leaflet width and length measurements. A. A mature first leaf (L1) of Arg. Lines with arrows at both ends indicate the distances measured for leaflet length (midrib) and width (side $b$ ). B. The double-ended arrows on the transverse sections indicate where side $b$ width was measured in folded leafets as well as in more mature leaflets. 


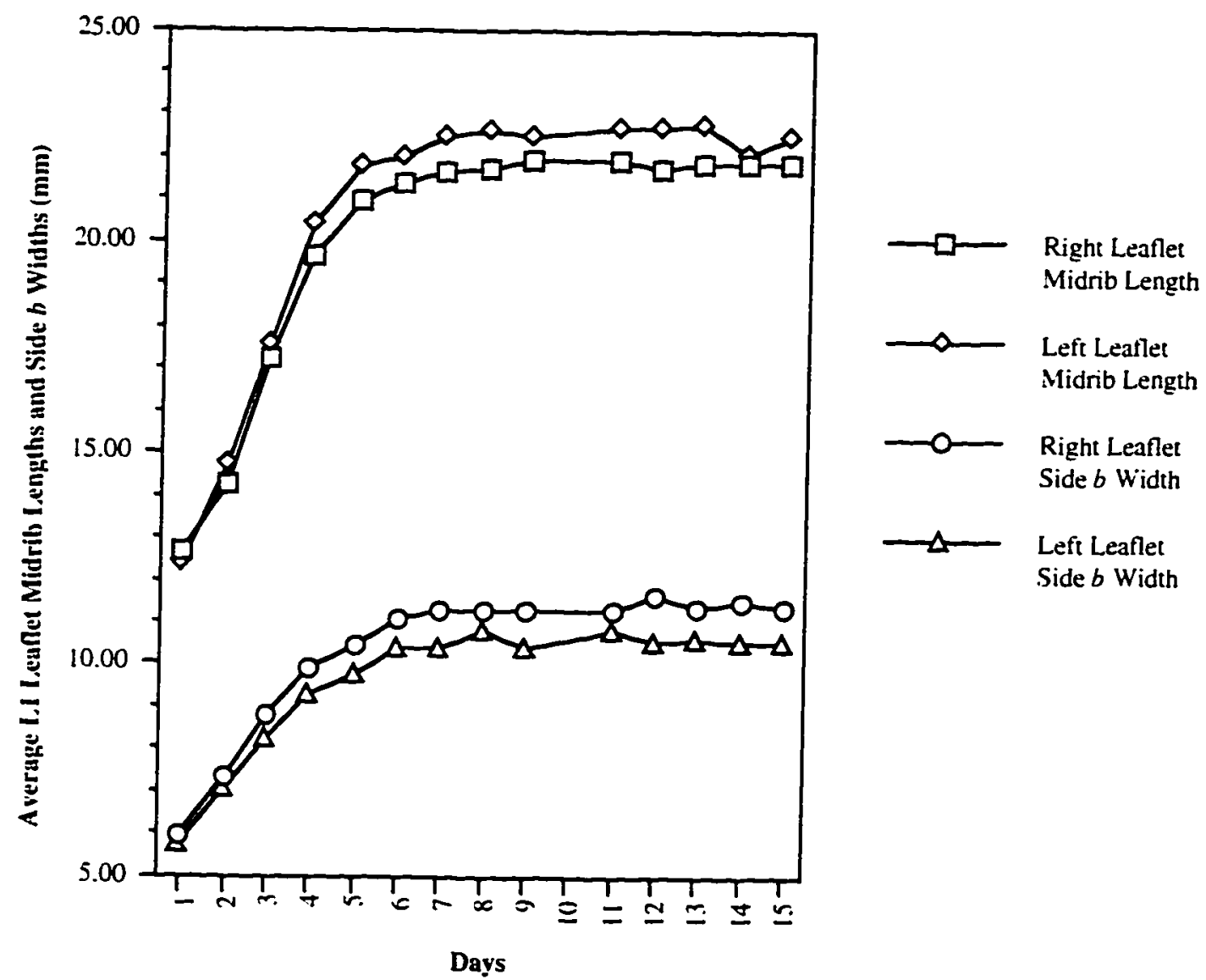

Fig. 28. Average daily midrib lengths and side $b$ widths of five experimental and five control leaflets of $L 1$ of Pisum sativum var. argenteum. Leaf expansion ceased by Day 10 . 


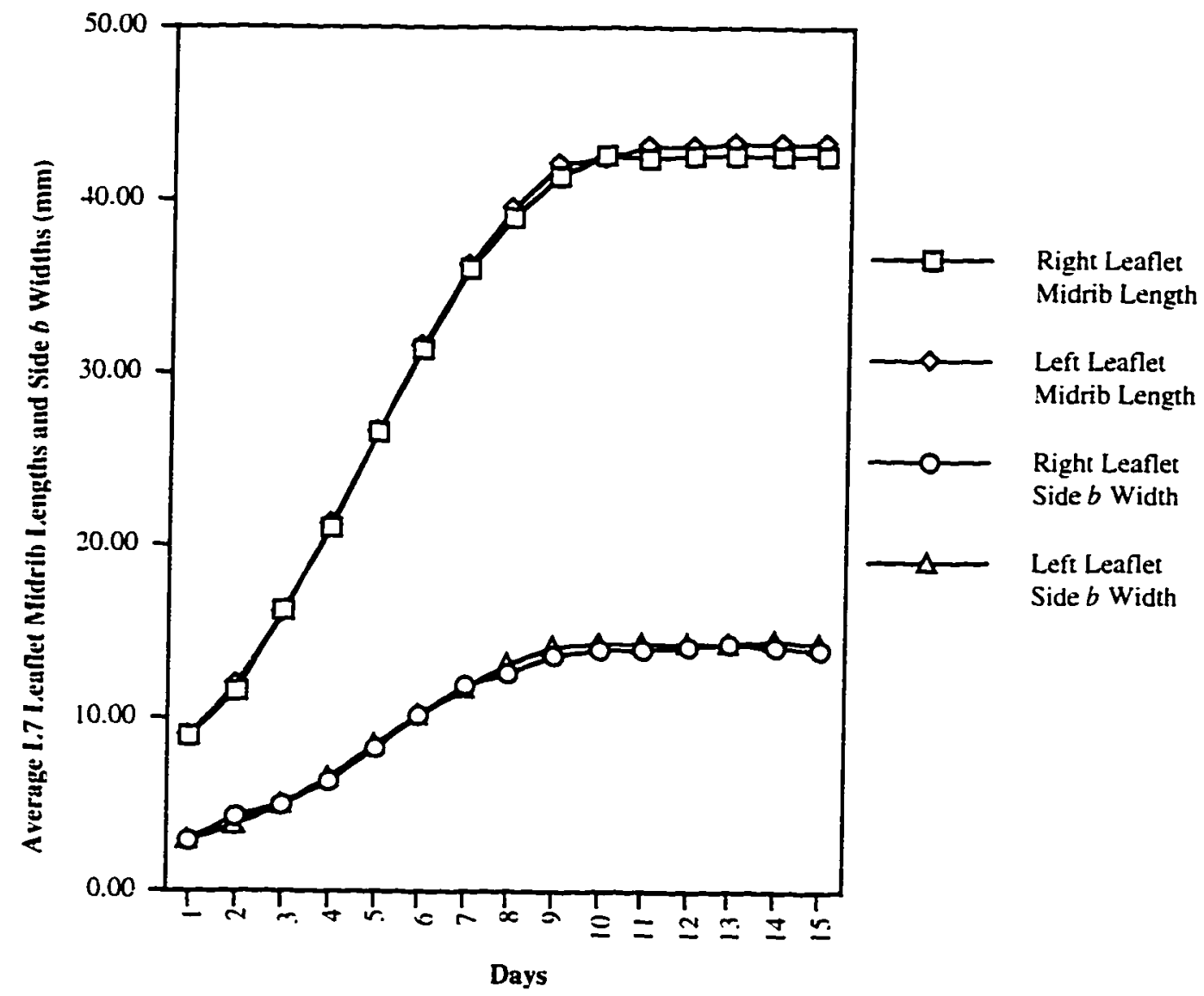

Fig. 29. Average daily midrib lengths and side $b$ widths of five experimental and five control leaflets of $\mathrm{L} 7$ of Pisum sativum var. argenteum. Leaf expansion ceased by Day 10 . 


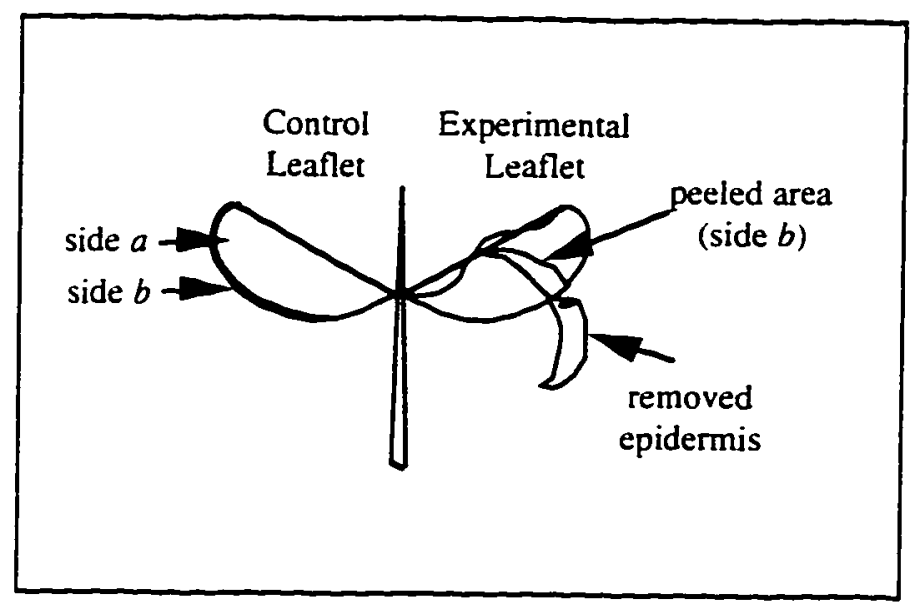

Fig. 30. Immature LI on Day 1. The right leaflet (experimental) has been unfolded and peeled. The left leaflet (control) has been left folded and intact. 